\title{
FOLIAR MORPHOLOGY AND ANATOMY OF THE GIGANTOPTERID PLANT DELNORTEA ABBOTTIAE, FROM THE LOWER PERMIAN OF WEST TEXAS ${ }^{1}$
}

\author{
Sergius H. Mamay, ${ }^{2}$ John M. Miller, ${ }^{3}$ David M. Rohr, ${ }^{4}$ \\ AND William E. STein, JR. ${ }^{5}$ \\ ${ }^{2}$ Department of Paleobiology, Smithsonian Institution, Washington, DC 20560; \\ ${ }^{3}$ Department of Botany, Oregon State University, Corvallis, Oregon 97331; \\ ${ }^{4}$ Department of Geology, Sul Ross State University, Alpine, Texas 79832; and \\ ${ }^{5}$ Museum of Paleontology, University of Michigan, Ann Arbor, Michigan 48109
}

\begin{abstract}
A B S T R A C T
Delnortea is a monotypic genus (type-species: $D$. abbottiae) of Lower Permian gymnosperms based on leaves from uppermost Leonardian deltaic sediments exposed in the Del Norte Mountains, West Texas. The leaves are simple, symmetrical, mostly oblong or elliptical, and vary in length from 1.2 to about $35 \mathrm{~cm}$. The petioles are short and stout, with a basally enlarged abscission zone. The margins are crenate, with a narrow, indurated border. Venation is in 4 orders: the secondaries and tertiaries are robust, unbranched, and pinnately arranged in a precise "herringbone" pattern, with the secondaries ending in the marginal sinuses; the quaternaries divide sparingly and fuse with others to form a dense reticulum of small meshes. Permineralized petiole and midrib material reflects a bifacial cambium, shown by a semicircular vascular arc, irregularly divided into several collateral bundles with secondary xylem and phloem. Delnortea is referable to the Gigantopteridaceae, a probably artificial family of gymnosperms incertae sedis with important venation features in common, but without known diagnostic reproductive organs. With Delnortea, the North American gigantopterids now include 5 genera, but Gigantopteris itself is lacking. Delnortea holds a relatively advanced evolutionary position among the American gigantopterids; its leaf morphology and gymnospermous anatomy entail intriguing points of comparison with Gnetum. The limited geographic and stratigraphic ranges and morphological distinctiveness of the American gigantopterids and associated taxa attest to rapid evolution and dispersal from a small area of origin in the southwestern United States during Leonardian time.
\end{abstract}

Permian PLANT MEGAFOSSILS were found in significant quantity in the Del Norte Mountains of West Texas in 1981 (Mamay, Miller, and Rohr, 1984). This site is one of only three new Permian plant localities to have been found in North America during the past two decades. One is in north-central Texas (Mamay, 1967), and the other is in Alaska (Mamay and Reed, 1984). All are important in containing new taxa or in their demonstration of botanical relationships with Asiatic floras of comparable age. Although the Del Norte deposit is geographi-

\footnotetext{
${ }^{1}$ Received for publication 1 July 1987 ; revision accepted 8 January 1988.

This study was partially funded by a grant from The Donors of the Petroleum Research Fund, administered by The American Chemical Society as Grant PRF 16160 B2C (DMR), and by National Science Foundation Grant BSR8306893 (WES). We thank J. R. Brown for allowing us to work on his ranch property. R. E. Grant, B. R. Wardlaw, and $\mathrm{E}$. L. Yochelson provided invertebrate fossil identifications and important paleoecological/stratigraphic interpretations; Zhang Renjie translated the necessary Chinese passages. H. N. Andrews, H. P. Banks, W. A. DiMichele, and $F$. M. Hueber read the manuscript and offered many valuable suggestions.
}

cally isolated from other Permian plant localities in the southwestern United States, the plant-bearing beds are easily correlated to the standard North American Permian sections in the nearby Glass Mountains. Consequently, the plant fossils are known to be younger than any other Paleozoic plant megafossils in North America.

The Del Norte flora is dominated by abundant impressions of detached leaves, of gigantopteroid general aspect (Mamay et al., 1984). The leaves form a remarkable series of size variants and have sufficient distinctive morphological features to make them easily separable from other, similar fossils. Furthermore, a small amount of permineralized material was found, providing an unusual opportunity for correlation of vascular anatomy with gross external foliar morphology. Although no other organs of this plant are known, the total present knowledge of the leaves amply warrants the recognition of a new genus; accordingly the new binomial Delnortea abbottiae was proposed recently (Mamay, Miller, Rohr, and Stein, 1986). The purpose of this paper is to more fully de- 


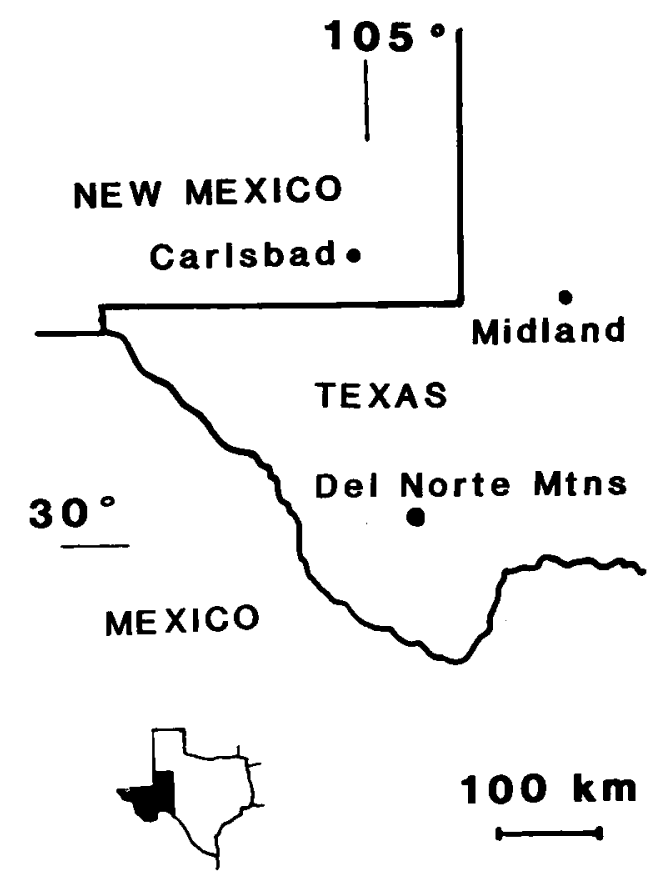

Fig. 1. Index map of West Texas. Delnortea locality indicated by large dot.

scribe the Delnortea material and discuss its significance.

MATERIAL AND METHODS-Geographic occurrence-The plant fossils were found in the Del Norte Mountains in Brewster County, western Texas (Fig. 1), late in 1981, when a few fragments were collected by a private geologic mapping party. The sample was given to Miller and Rohr, who began excavation of the site. The productive beds are on the Altuda 77 Ranch, then owned by J. R. Brown. This exposure is $30 \mathrm{~km}$ southeast of the town of Alpine and $1.7 \mathrm{~km}$ south of Bird Mountain summit $\left(30^{\circ} 19^{\prime} \mathrm{N}, 103^{\circ} 31^{\prime} \mathrm{W}\right.$; USGS Bird Mountain 7 $1 / 2$ minute quadrangle map, 1972). The elevation is $5,030 \mathrm{ft}$, and the Glass Mountains are visible to the east. This is the southernmost occurrence of Permian plant megafossils presently known in North America; aside from one limited collection from Hudspeth Co. (Albritton and Smith, 1965), these are the only Permian plant specimens known from Trans-Pecos Texas.

Manual excavation was difficult because of the steep dip of the fossiliferous beds and the thick overburden, but the sympathetic landowner generously made a bulldozer available to us. Sufficient overburden was removed that directions of dip and strike could be determined, and access was gained to about $50 \mathrm{~m}$ of fossiliferous rock face. The fossils occurred in fair abundance in a $10-\mathrm{m}$ thick sequence of gray or tan laminated mudstone and calcareous siltstone; this is overlain by an unfossiliferous conglomerate of graded pebbles to gravel-sized clasts.

After the bulldozing, manual excavation proceeded intermittently, but with rapidly diminishing success. Sparse, low-quality leaf impressions were found at a second locality, about $1 \mathrm{~km}$ to the south. A third locality was found about $200 \mathrm{~m}$ to the northwest and 75 $m$ higher in the section than the Delnortea beds; there, a conglomerate unit contains locally abundant fragments of silicified wood of $D a$ doxylon sp., some as much as $30 \mathrm{~cm}$ in diameter.

Geologic setting and depositional environment-Rocks of the Wolfcampian and Leonardian stages of the Permian System are wellexposed in the Glass and Del Norte mountains of West Texas. Stratigraphic subdivisions of those rocks were first detailed by P. B. King (1931) and R. E. King (1931), who recognized two facies: a predominantly siliceous western facies, and a carbonate facies to the east. Later biostratigraphic work, particularly that of Cooper and Grant (1972), deals with the eastern facies in the Glass Mountains, where well-preserved silicified marine invertebrates are abundant. Fossil plant material is uncommon throughout the area, where it occurs mostly as silicified wood fragments and rare, poorly preserved remnants of foliar or fertile parts. The voltzialean cone Moyliostrobus texanum (Miller and Brown, 1973) is an unusually fine exception.

The western facies, as exposed in the Del Norte Mountains, contain interbedded siltstone, mudstone, shale, and carbonate with minor conglomerate, representing shallow subtidal, intertidal, and probably deltaic environments. These facies formed along the southern edge of the petroliferous Permian $\mathrm{Ba}-$ sin, with the clastic material being derived from the uplifted Marathon foldbelt. The mudstonesiltstone sequence containing the Delnortea beds is in a section originally mapped by P. B. King (1931) as lower Word Formation (Guadalupian); later this was assigned by Cooper and Grant (1972) to the older Road Canyon Formation (uppermost Leonardian).

Stratigraphic control is provided by conodonts in limestones closely bracketing the Delnortea beds. Limestone samples were collected by B. R. Wardlaw, who isolated and examined the conodonts. According to Wardlaw (personal communication, 1983), the conodonts indicate age equivalence of these lime- 


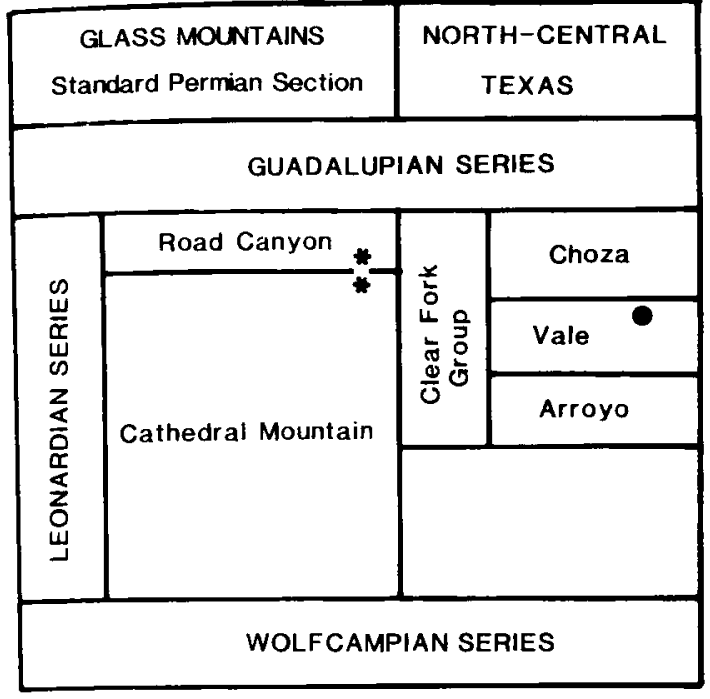

Fig. 2. Generalized correlations of the Permian formations of the Glass Mountains and north-central Texas, modified from Cooper and Grant (1972) and Dunbar et al. (1960). Asterisks bracket the possible limits of the Delnortea range, as indicated by associated conodonts; the black dot indicates the next highest Permian plant megafossil occurrences known in North America.

stones with the lowermost part of the Road Canyon Formation or the uppermost part of the Cathedral Mountains Formation in the Glass Mountains section. Both formations are of uppermost Leonardian age; according to the most reliable summaries (Dunbar et al., 1960), the Delnortea beds correlate with the Choza Formation in north-central Texas (Fig. 2). The Choza Formation is rich in terrestrial vertebrate fossils but is not known to contain plant megafossils except for rare occurrences of unidentifiable fragments in its lower and middle units (Olson, 1958). The Vale Formation, however, is locally rich in plant megafossils, some well-preserved (Read and Mamay, 1964). Before the discovery of Delnortea the Vale floras were regarded as the youngest Paleozoic plants in North America, but Delnortea is demonstrably younger.

The environment of deposition of the Delnortea beds is interpreted as a marginally marine setting with low-energy introduction of plant material into the finely laminated enclosing sediments. The Delnortea specimens are large and most are broken, but they show little evidence of abrasion. The fossiliferous sequence contains horizontal burrows in some beds, as well as occasional marine gastropod shells, some occurring on the same bedding plane as plant fragments. The gastropods include forms similar to bellerophontaceans and pleurotomariaceans found in late Paleozoic

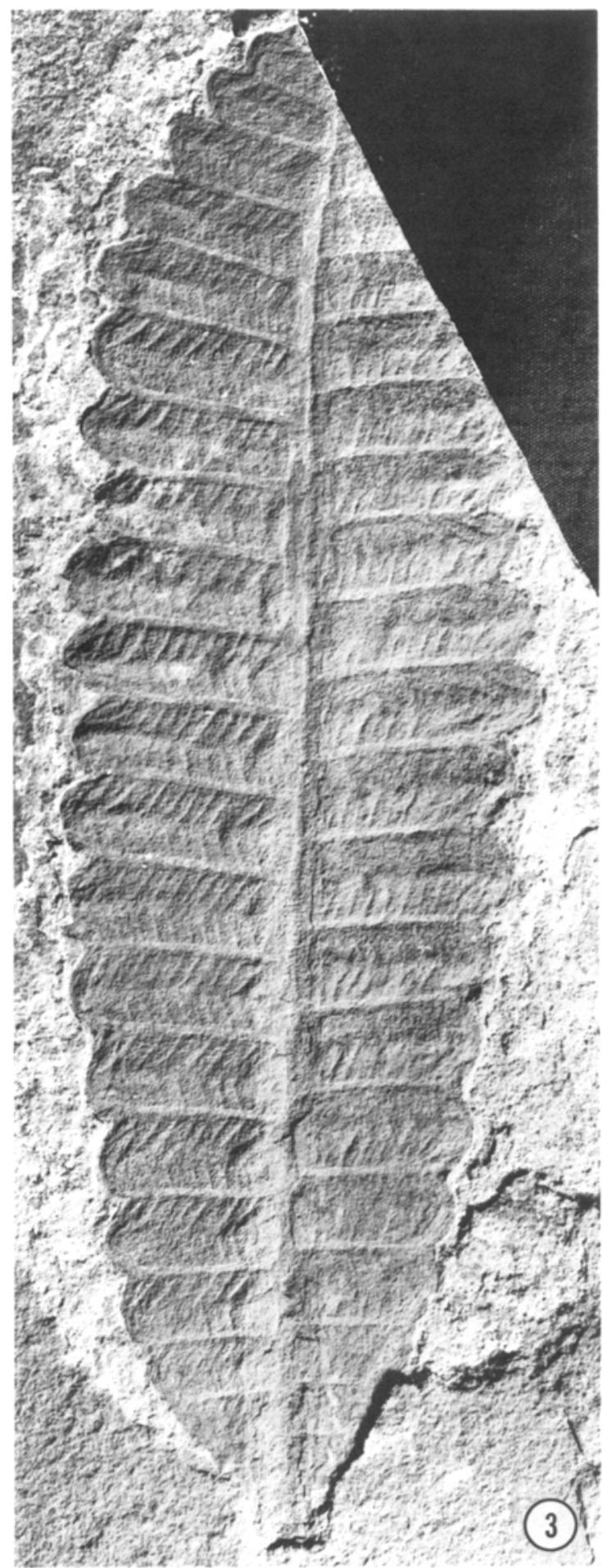

Fig. 3. Delnortea abbottiae. Large leaf, complete except for diagonally broken tip and incomplete petiole. Note crenate margins, sinal termination of secondary veins, and regular chevron-like or "herringbone" pattern formed by tertiary veins; quaternary veins only faintly visible. USNM $364419, \times 1$. 


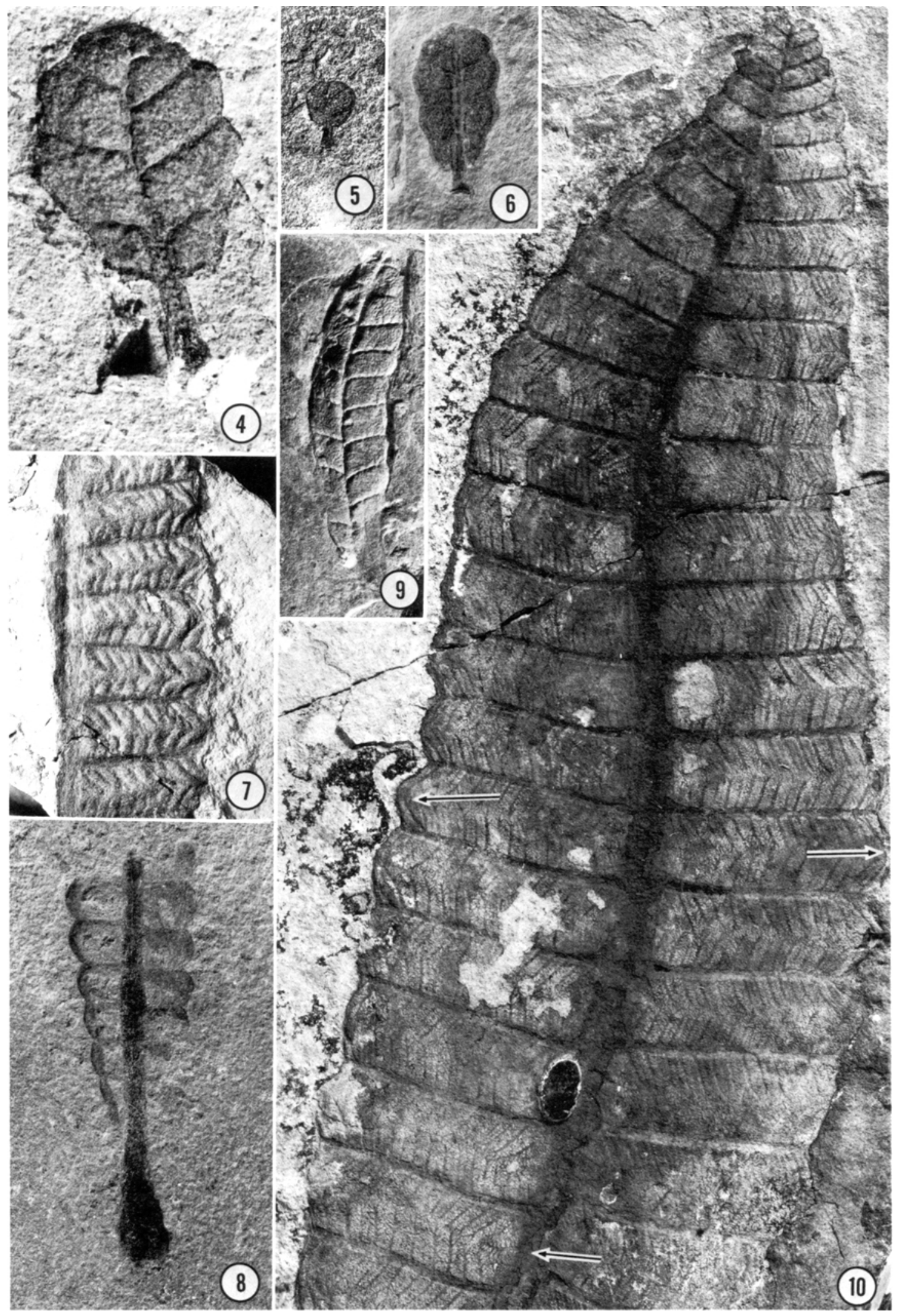


deltaic sequences in north-central Texas (E. L. Yochelson, 1983, personal communication). The marine shells within the plant beds, the conodont-bearing limestones above and below, and the overlying graded-gravel conglomerates indicate proximity to, and episodic inundation by, marine waters. A deltaic depositional interpretation is consistent with the overall evidence.

Composition of the flora-Although plant material is abundant, few taxa are represented. The most prominent associate of Delnortea is Taeniopteris, represented by several fragments of large leaves; three specimens have structures suggestive of either ovulate or polleniferous organs. At the main plant deposit a few platyspermic seeds and small shoots clothed with short needle-like leaves represent a minor coniferous element, while abundant silicified fragments of wood of Dadoxylon sp. occur in the conglomerate slightly higher in the section. Pecopterid and sphenopsid material is rare, and palynomorphs are absent (R. M. Kosanke, personal communication, 1983). The problematical specimen seen in Fig. 20 is the only one of its kind; its several triangular segments are either attached to or are accidentally superimposed upon a stout axis and have parallel grooves suggestive of a venation pattern not known in Delnortea.

Preservation, preparation methods - The Delnortea leaves occur as impressioncompressions or rarely as partially permineralized specimens showing anatomical details. The compressions and impressions are essentially flat, but may have varying degrees of vaulting or surface relief caused by the imprints of stout veins and foliar margins upon the matrix.

Iron oxides are concentrated along the vascular patterns and the pinkish, reddish brown or dark brown stains contrast strongly with the generally gray coloration of the matrix, thus simplifying visual examination and photog- raphy (Fig. 10). Another photogenically favorable type of preservation is shown in Fig. 16 , where the midrib, secondary veins and foliar margins are heavily coalified while the remainder of the lamina has only minor coalification.

An unusual example of surficial coloration is seen in Fig. 11 and 12, both unretouched photographs. In this unique specimen, the leaf is readily distinguished from the matrix but the contrast is not great, because the leaf itself is dark brown while the matrix is a very dark gray. However, the leaf outline is sharply delineated by a thin whitish deposit of undetermined mineral matter. This continues without interruption along the leaf margin as well as the sides and the truncated base of the petiole.

A few specimens are permineralized by a complex mixture of calcite and hydrated iron oxides (limonite); three specimens show sufficient structure for detailed description. These contain only minor amounts of organic material, usually restricted to the walls or lumina of tracheids, bundle sheath cells, or other thickwalled cells in both midrib and lamina. In many regions, structural detail is lacking or available only as subtle color differences in the permineralizing minerals.

Several techniques were attempted to enhance details of this material, including thinsections, surface polishes and etches (Stein, Wight, and Beck, 1982), and scanning electron microscopy. The best preparations resulted from simple surface polishes, using \#1000 carborundum or aluminum oxide; these were mounted on glass slides with no additional treatment. A total of 64 transverse and 43 longitudinal sections of the petiole and midrib, and 62 sections of the lamina were made. Some additional permineralized material remains unprepared. The relative positions and spacing of all sections were recorded; these notes, along with all the studied material of Delnortea, are deposited in the paleobotanical collections of the United States National Museum, Washington, DC.

Fig. 4-10. Delnortea abbottiae. 4. Small leaf with stout petiole, crenate margin, and sinally terminate secondary veins. USNM $387469, \times 2.5$. Smallest leaf known. Note nearly oval outline, stout petiole, widely spaced secondary veins, and indurated border of lamina. USNM $387470, \times 1.6$. Larger leaf, with relatively more elongate lamina and shallowly crenate margin. Short, stout petiole has a flaring, concavely crescentic base. USNM $364418, \times 1.7$. Part of lamina to right side of a midrib, showing "herringbone" pattern in deep surficial relief, as impressed by unusually strong secondary and tertiary veins. USNM $387471, \times 1.8$. Base of leaf, showing broad midrib, crenate margin, and very robust, flaring petiole base. USNM $364417, \times 1.9$. Moderately small leaf with deep impressions of midrib, secondary veins, and slightly inrolled margin. USNM 387472, × 1. 10. Largest known specimen, basally incomplete. Tertiary veins clearly visible; quaternary veins preserved in some areas. Upper arrows indicate loop-like continuity between opposing pairs of tertiary veins; the small area (arrow) below the dark concretion near the base of the specimen is shown enlarged in Fig. 18. USNM 387473, ×1. 


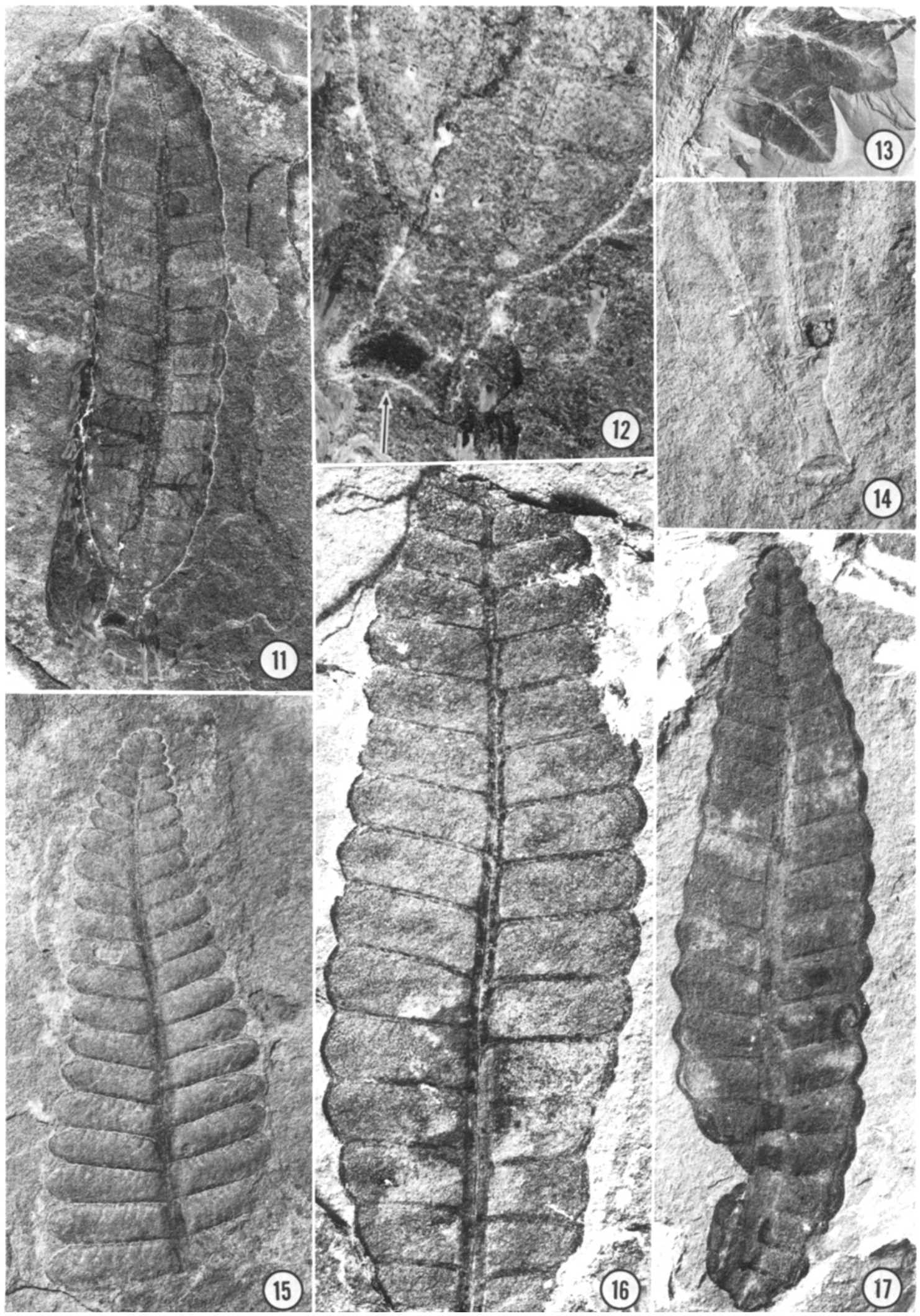


DESCRIPTION - The Delnortea hypodigm consists of 5 detached, complete leaf specimens, 4 of which are illustrated here (Fig. 4 6,11 ), and several dozen additional specimens in variously fragmentary condition. Three specimens are partially permineralized and furnish internal anatomical detail. This suite of specimens shows an extraordinary size range, but consistent qualitative features establish a basis for the generic concept.

General morphology and leaf architecture (terminology partly adapted from Hickey, 1979)-Delnortea is characterized by simple, petiolate leaves with entire to crenate margins. The laminae are mostly preserved as flat, apparently stiff bodies with no natural or even accidental folding; in a few specimens, however, the lamina shows fairly prominent vaulting between secondary veins (Fig. 15). Minor inrolling of the margins is present but infrequent (Fig. 37), and slight curvature or sinuosity of the lamina occurs in a few specimens (Fig. 15). The inrolling is not sufficiently pronounced or consistent to warrant interpretation as revolute prefoliation, although that possibility exists. Otherwise there are no indications that foliar vernation of Delnortea was other than the erect type.

A few specimens have a thin, deep median groove on the upper surface of the lamina, resulting from the fact that the lamina is attached to only a minor part of the adaxial side of the midrib. This groove is clearly seen in sectional views (Fig. 26, 29), but its observation in surficial views is dependent on the plane exposed when the matrix was split. In some specimens the splitting occurred along the abaxial surface, exposing the lower side of the midrib (Fig. 22) and obscuring the upper. In others, the midrib shows nothing that definitely identifies the surface as upper or lower. Figure 16, however, is an unusually instructive specimen in which the fossilizing processes produced a clear surficial portrayal of the midrib, with its blackened residue, and the median groove, seen as a thin white line along the middle of the midrib. Three-dimensional aspects of the midrib-laminar groove relationships are remarkably demonstrated in Fig. 23, in which the permineralized midrib lies in place against the impression of the adaxial surface of the lamina. Above the point where the midrib was broken, the leaf surface is exposed and the median groove extends distally as a thin, welldefined ridge in the matrix. Similar grooves depart from the median one, sharply defining the origins and courses of three successive secondary veins (Fig. 23, arrow).

Excluding petioles, the leaves range in length from only $8.0 \mathrm{~mm}$ in the smallest complete specimen (Fig. 5) to $92.0 \mathrm{~mm}$ in the largest (Fig. 11). The remaining unbroken leaves (Fig. 4,6 ) have laminae no more than $25.0 \mathrm{~mm}$ long. Some specimens have either a broken tip or base, but many are sufficiently complete that lengths are easily estimated. For example, the nearly complete specimen shown in Fig. 3 probably was about $19.0 \mathrm{~cm}$ long. The largest specimen yet found (Fig. 10) is an incomplete fragment $25.0 \mathrm{~cm}$ long, and we estimate that its lamina was at least $30.0 \mathrm{~cm}$ long. Widths range from $8.0 \mathrm{~mm}$ in the smallest leaf (Fig. 5) to $8.5 \mathrm{~cm}$ in the largest (Fig. 10), with most specimens in the $3.0-5.0 \mathrm{~cm}$ range.

The laminae are symmetrical in outline and vary in shape from orbiculate, with a lengthwide ratio of $1: 1$ (Fig. 5) to linear-lorate, with a $1 / w$ ratio of at least $5: 1$; most specimens are elongate-elliptic. Two specimens are notable because of the very narrow, cuneate configuration of their laminar bases (Fig. 8, 14). With their thick petioles and the very gradual increase in laminar width, these specimens seem to represent exceptionally long, narrow leaves with $1 /$ w ratios of even more than 10:1.

Laminar apices (Fig. 10, 11, 15, 17) and bases (Fig. 6, 8, 9) are mostly acute with shallowly convex margins. A few apices, however, are obtuse (Fig. 4, 5, 16), as are two known bases (Fig. 4,5 ). The same specimen may have an obtuse apex and acute base (Fig. 6), and where

Fig. 11-17. Fig. 11-12, 14-17. Delnortea abbottiae. 11. Largest known complete specimen, with typically crenate margin and sinally terminate secondary veins; tertiary veins indistinct. Note cleanly truncated, concave abscission zone at base of petiole. USNM 387474, $\times 1$. 12. Enlargement of base of specimen shown in Fig. 11 ; arrow indicates abscission zone. USNM 387474, $\times 3$. 13. Basal portion of one side of lamina of Gigantopteridium americanum (White) Koidzumi. Midrib at left, with two secondary veins at right, terminating at tips of two laminar lobes. USNM $387475, \times 1.14$. Base of Delnortea leaf, with nearly straight margins, very broad petiole, and well-defined abscission zone; secondary veins and marginal border also seen. USNM $387476, \times 1.15$. Distal portion of leaf, with unusually deep marginal sinuses. USNM $387477, \times 1.16$. Holotype of $D$. abbottiae; nearly complete leaf, except for broken tip and base. Note median groove on midrib, conspicuous black thickening of marginal border, and regular termination of secondary veins in marginal sinuses. USNM $364416, \times 1,17$. Leaf with strong marginal induration and an apparently healed damaged area near base of left side. USNM $387478, \times 1$. 


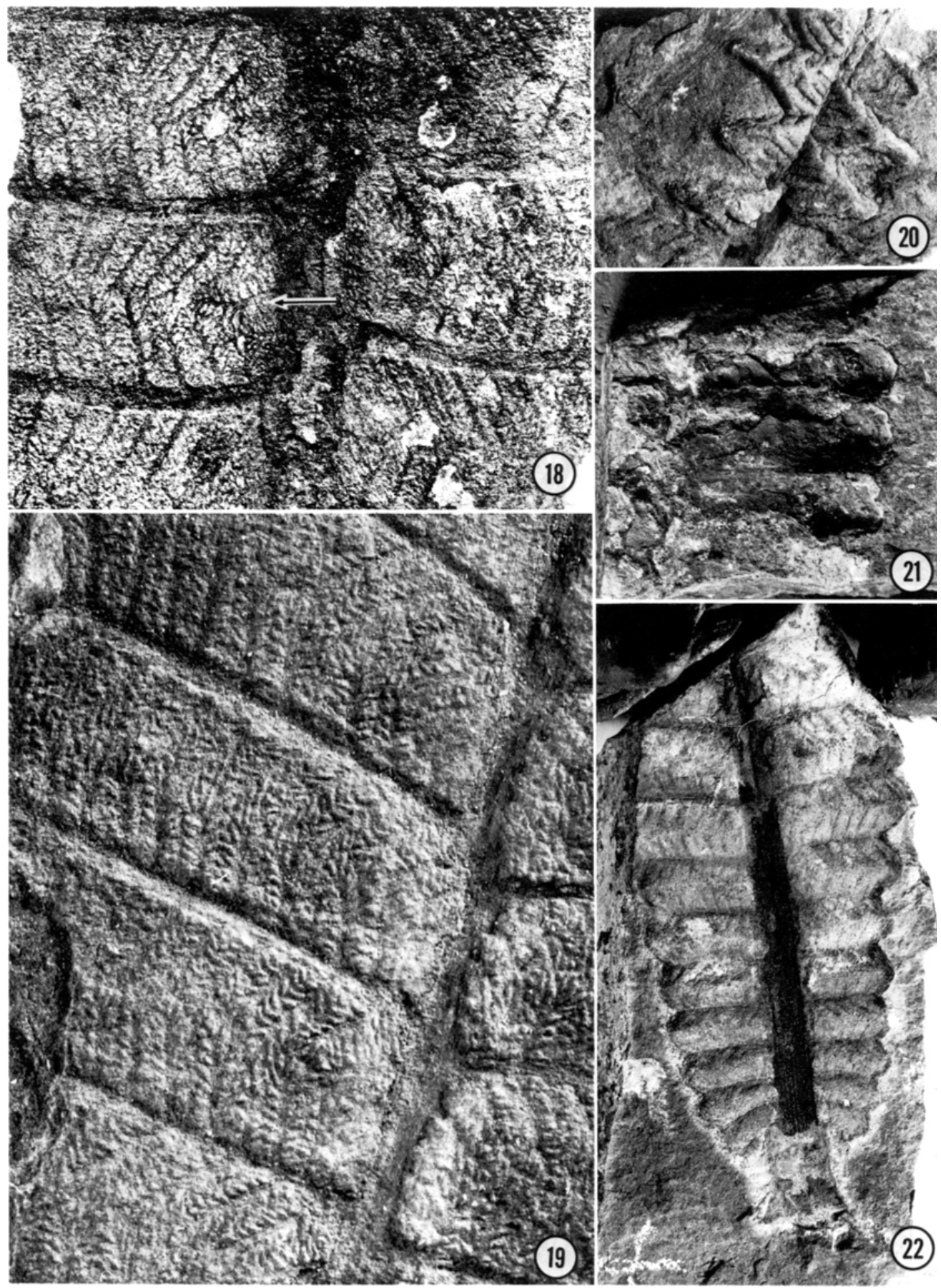

Fig. 18-22. Fig. 18, 19, 21, 22. Delnortea abbottiae. 18. Enlargement of small area indicated by arrow in Fig. 10. Figure shows small generally oblong meshes formed by interfusion of coalified tertiary and quaternary veins; arrow indicates area where tertiaries arise directly from midrib. USNM $387473, \times 2.19$. Small area of leaf, with all four orders of veins seen as noncoalified impressions. Chevron-like arrangement of meshes clearly evident in several areas. USNM 364420, $\times 2$ 2. 20. Unusual specimen associated with Delnortea, consisting of two oppositely directed series of deeply grooved, wedge-like laminar segments, either attached to or accidentally superimposed on a stout axis at center 
observable, the ultimate tips are rounded (Fig. 4-6, 17).

The leaf margins are delineated by a narrow border of thickened tissue, particularly well shown in Fig. 16 and 17. This appears as a dense, coalified line that conforms precisely with the marginal undulations and extends uninterruptedly over the leaf tip (Fig. 17). This unusual feature is seen in many of the large leaves, although not as well preserved (Fig. 8, $12,14)$. It appears in even the smallest leaves (Fig. 4-6), and its consistent presence establishes it as a natural feature in Delnortea.

The margins are otherwise characterized by regularly spaced, rounded crenations of varying prominence (Fig. 3-12, 14-17, 22). These are usually of low profile (Fig. 17), but they vary from almost imperceptible bulges (Fig. 9) to high-domed projections, equal in height to the distance between adjacent sinuses (Fig. 15). The crenations may be as much as $15 \mathrm{~mm}$ wide (Fig. 10), but widths of $10 \mathrm{~mm}$ or slightly less are most common in the larger fragments (Fig. 3 , 16). Widths of crenations are uniform through most of the length of a given leaf (Fig. 3,11 ), with only gradual diminishment toward the leaf base (Fig. 3, 22) or apex (Fig. 15, 17). Crenations are well-developed in the smaller specimens (Fig. 4, 6) and even the smallest leaf (Fig. 5) faintly shows this type of margination.

The sinuses between adjacent crenations are the only form of regular incisions of the $\mathrm{Del}$ nortea leaf margin. The deepest sinuses are acutely angular (Fig. 15); others are only shallow marginal concavities (Fig. 11). In some specimens, low rounded crenations alternate with equally rounded sinuses, resulting in a shallowly sinuous leaf margin (Fig. 17).

An aberrant marginal feature is also shown in Fig. 17, where an asymmetrical embayment extends into the lamina as far as the midrib; this is the only such irregularity seen in $\mathrm{Del}$ nortea. The sides of this deep concavity have shallow but fairly regular crenations, suggesting trauma during development of the lamina, with no phylogenetic significance.

Several specimens have petioles, but only 8 are complete; 7 are illustrated here (Fig. 4-6, $8,11,14,22)$. The petioles are short and stout, with a relative length of about one-quarter that of the lamina in the smallest leaf (Fig. 5). In larger leaves the proportionate length of the petiole decreases; in the largest complete leaf
(Fig. 11), the petiole is $8 \mathrm{~mm}$ long, or slightly less than 10 percent the length of the lamina. The longest petiole is $22 \mathrm{~mm}$ (Fig. 8).

Petiolar width, measured at the base of the lamina, ranges from slightly less than $2 \mathrm{~mm}$ in the smallest leaf(Fig. 5) to $10 \mathrm{~mm}$ in the broadest petiole (Fig. 22). Most petiolar surfaces are unornamented, but one specimen (Fig. 14) has a series of minor, probably insignificant transverse wrinkles. Another petiole has distinctive longitudinal ribbing that continues onto the midrib surface; similar ribbing appears on the midrib shown in Fig. 22.

The most notable external feature of the petioles is the basal configuration. Proximally, the petioles show a slight increase in width, usually ending in a flared, truncated structure suggestive of a clasping function (Fig. 5, 6, 11, 12, 14, 22). The specimen seen in Fig. 8, however, has a rounded, club-shaped base, which is probably an artifact of incomplete preservation.

Particular interest lies in the two petioles shown in Fig. 11, 12, and 14. In Fig. 11 and 12 , the petiole base, as demarcated by the thin line of whitish mineral matter, ends in a perfectly defined, shallowly concave, arced truncation. This arclike mark is duplicated exactly in Fig. 14. Here, however, the arc is slightly elevated and the area between its ends is delineated by a nearly straight margin, lending the petiole base a three-dimensional, crescentic aspect, reminiscent of the base of an abscissed megaphyllous leaf. These features suggest that a well-developed abscission layer was responsible for defoliation in Delnortea.

Venation: Delnortea leaves have a complex vasculature consisting of four orders of veins, considering the midrib as of the first order. All subsidiary veins depart pinnately with great regularity; this symmetry persists even as far as the ultimate (quaternary) veins (Fig. 19). The latter are seen only in a few of the better specimens (Fig. 10, 18,19) but the stronger veins are sufficiently thick that their positions are plainly indicated as depressions on the matrix even where no coalification or mineral encrustation is present (Fig. 7, 9).

The midribs are straight, with only a few showing a slight curvature (Fig. 4, 9) or sinuosity (Fig. 10). The midribs are very thick and robust (Fig. 3, 22, 23); they gradually diminish proximally but persist, without becoming di-

of bottom of photograph. USNM $387479, \times 1.21$. Impressions of three oval objects, apparently marginal on Delnortea fragment. USNM $387480, \times 1.22$. Leaf fragment with unusually stout midrib, marked by longitudinal striations slightly below median portion. USNM $387481, \times 1$. 

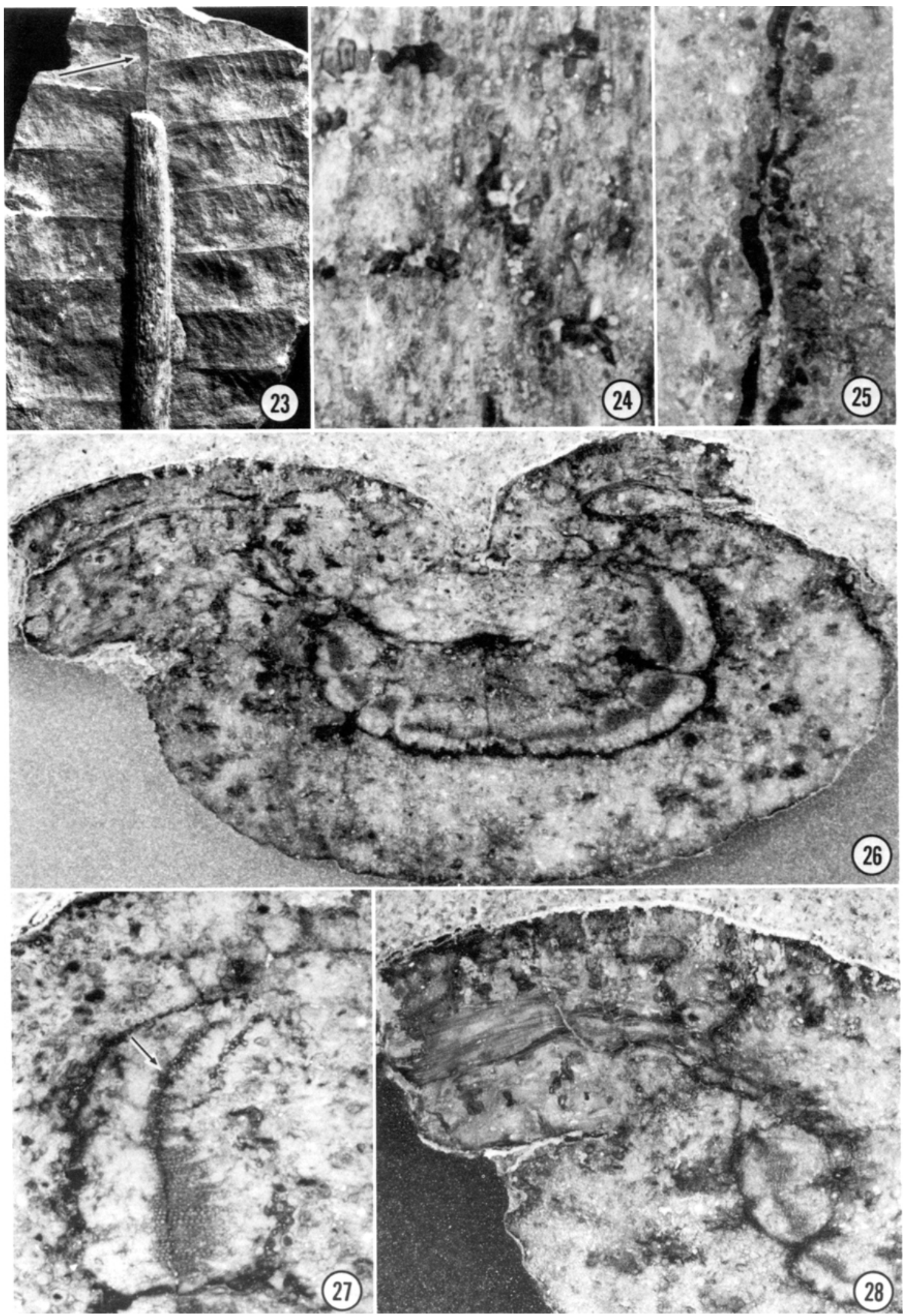

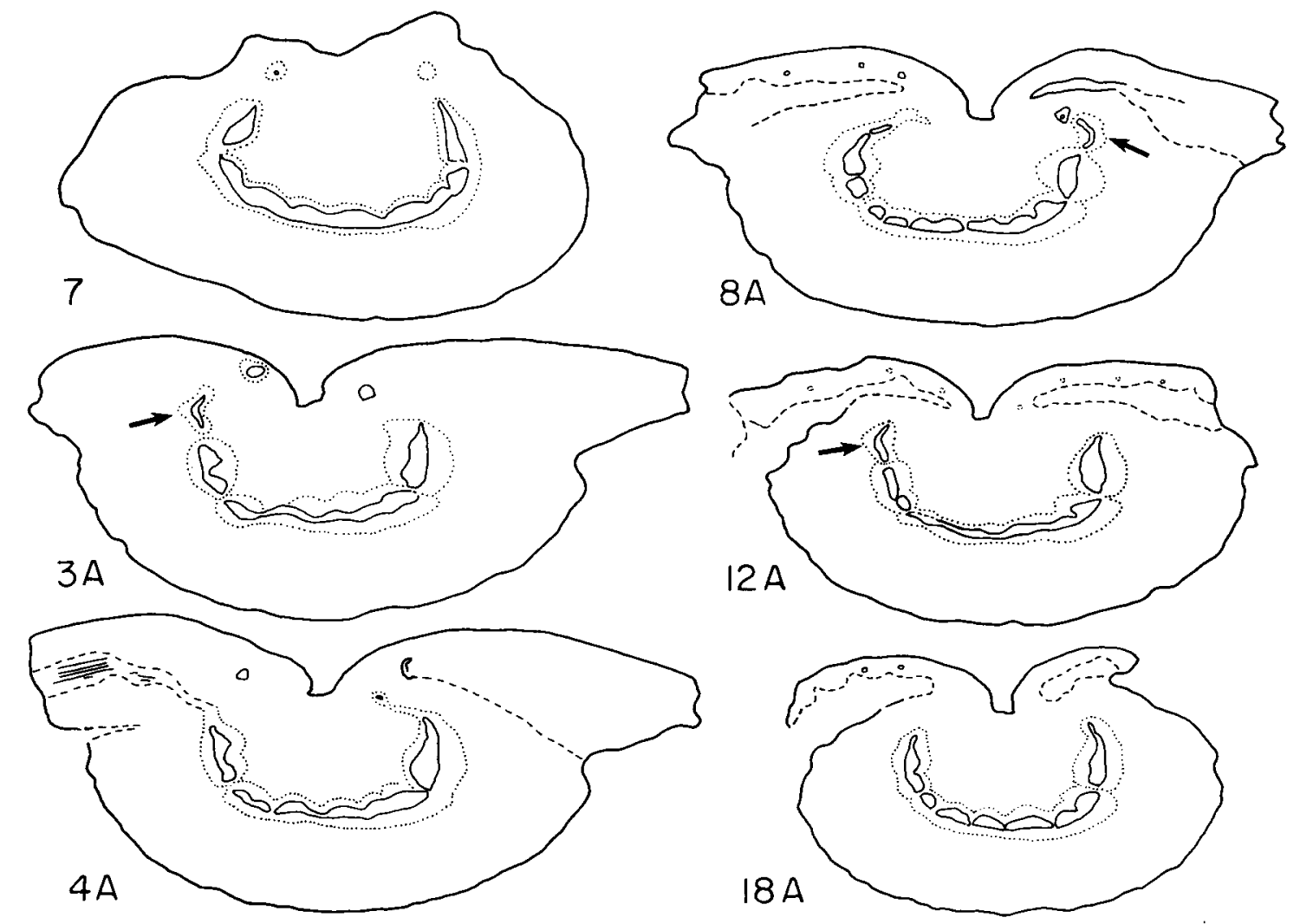

\section{0}

$5 \mathrm{~mm}$.

Fig. 29. Delnortea abbottiae. USNM 372427; section numbers in parentheses. Serial camera lucida drawings of petiole and midrib, showing changes in configuration of vascular tissues and attachment of lamina. Solid lines indicate perimeter of specimen and approximate limit of the xylem, dotted lines the limit of vascular tissues, and dashed lines either adaxial surface of midrib or abaxial surface of attached lamina. Petiole (7) at upper left,distal section of midrib $(18 \mathrm{~A})$ at bottom right. Numbers ( 7 and $3 \mathrm{~A}-18 \mathrm{~A}$ ) reflect origin from different series of sections approximately $6 \mathrm{~cm}$ apart; read series from top to bottom, starting at left.

vided or diffuse, to the tip of the laminae. These characteristics are well-developed in even the smallest leaves. The midrib seen in Fig. 23 is exceptional because of its great width $(9 \mathrm{~mm})$ compared to the overall width (about $60 \mathrm{~mm}$ ) of the leaf. Special interest attends the fact that this midrib is not only the most robust one in the collection but also is preserved by permineralization and is only slightly compressed, as seen in sectional views (Fig. 26, 30). The surface of this specimen has narrow and closely spaced longitudinal ribs, which might represent impressions of the multiple bundles of the vascular system (Fig. 30).

The secondary veins are prominent, unbranched and mostly seen as impressions (Fig. $3,4,15,19$ ); in some leaves the secondaries are delineated by coalified residue (Fig. 16) or

Fig. 23-28. Delnortea abbottiae. All photographs of USNM 372427; section numbers in parentheses. 23. Leaf with portions of petiole, midrib and lamina structurally preserved; note impressions of median groove (arrow) and of secondary and tertiary veins. $\times 0.85$. 24. Longitudinal section of outer ground tissue with several clusters of thickwalled, isodiametric sclerotic cells. (20AL2), $\times 42$. 25. Transverse section in region of sclerotic hypodermis. $(7), \times 53$. 26. Transverse section of midrib, showing the vascular arc in center, attached lamina (top right), and ground tissues of a secondary vein (top left); vascular bundles consist of dark xylem areas with lighter phloem areas to the outside, the whole delimited by a very dark boundary layer. $(4 \mathrm{~A}), \times 16.27$. Transverse section of vascular bundle of midrib, showing incipient trace to secondary vein (arrow); note cells of both inner and outer boundary of vascular tissues. $(18 \mathrm{~A}), \times 36$. 28. Longitudinal section of secondary vein at level of departure from midrib; lamina at top, vascular bundles of midrib seen in transverse section at lower right. $(4 \mathrm{~A}), \times 22$. 


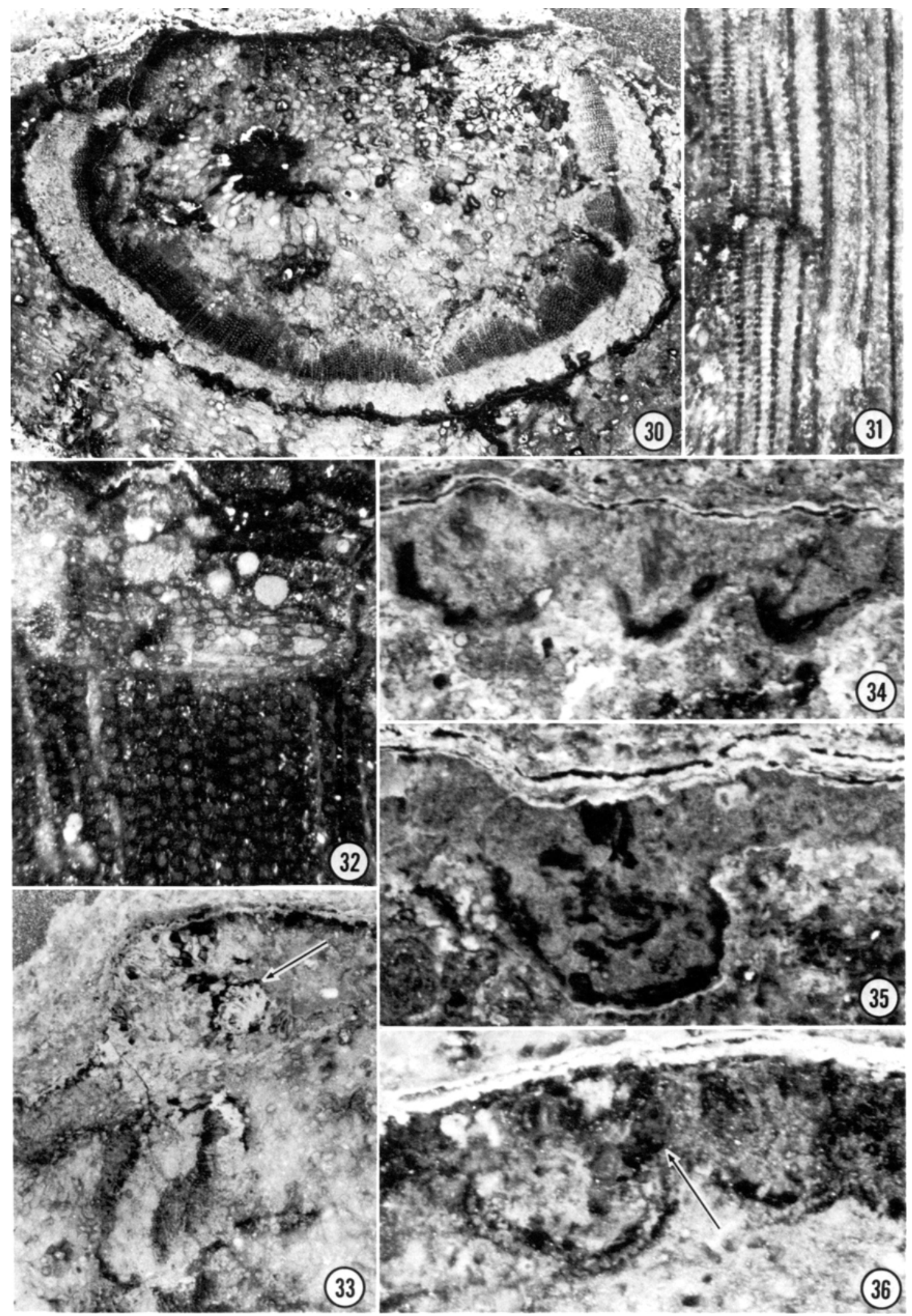




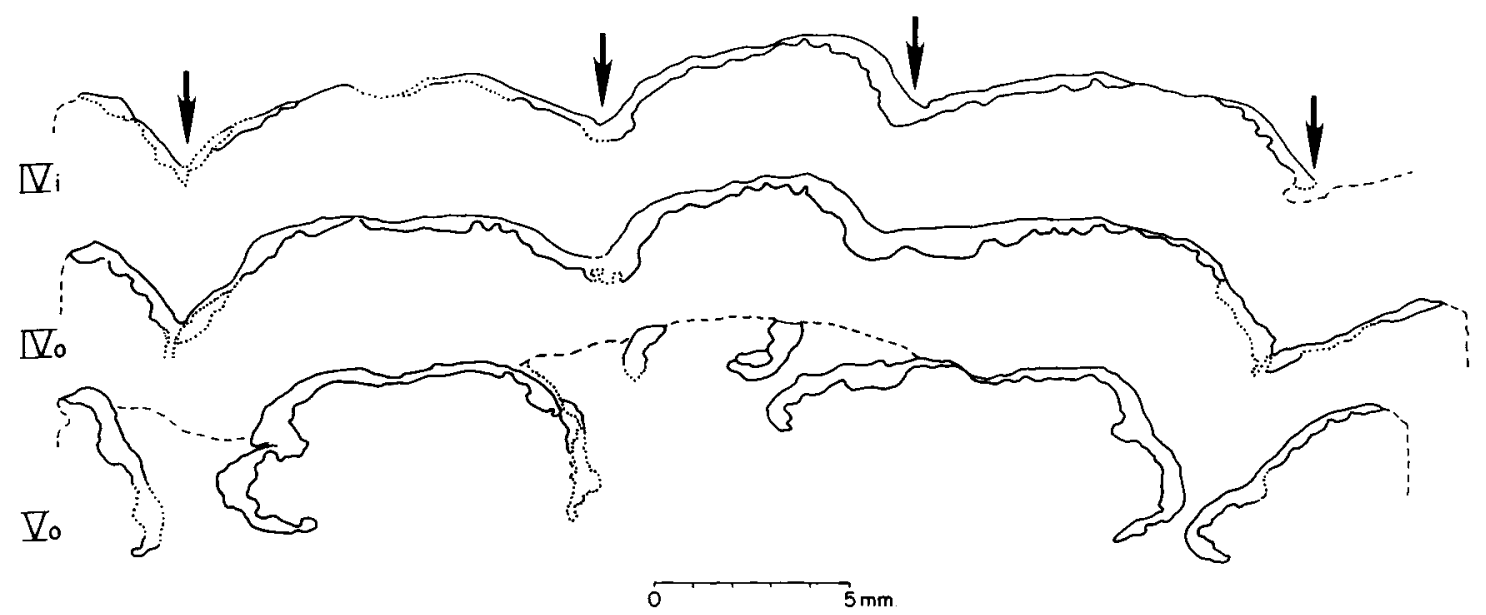

Fig. 37. Delnortea abbottiae. Serial camera lucida sections of lateral portions of lamina, showing relationship between distal secondary veins (arrows) and recurved edges of marginal lobes. Solid and dotted lines represent boundary of lamina, dotted lines the better preserved areas; dashed lines show approximate limit of specimen. Section closest to midrib at top (IVi); section through marginal lobes at bottom (Vo).

limonitic stains (Fig. 10), while others exhibit only the impressions of the median grooves (Fig. 9, 23). Most secondaries are straight, but in some leaves they bend outward sharply a short distance distal to the points of divergence from the midrib (Fig. 9, 16); rarely the secondaries proceed proximally before bending outward (Fig. 10, 18). Angle of divergence of the secondary veins usually is nearly perpendicular (Fig. 3, 7, 8), with many departing at broadly acute angles (Fig. 4, 9), particularly toward the leaf apex (Fig. 15, 17). Proximally a few of the secondaries may create slightly obtuse angles (Fig. 22).

The secondaries are pinnately arranged, usually in opposite positions. Subopposite or alternate veins are common, but the transitions are gradual and all variations may appear on the same leaf (Fig. 10). The spacing of secondaries is very regular, with intervals between veins reaching as much as $15 \mathrm{~mm}$. Distally the secondaries may gradually become more crowded, but they remain distinct as far as the leaf tip.
Secondary venation of the smallest leaves is notable because of the wide spacing of veins relative to the size of the leaf(Fig. 4-6, 9). With intercostal spaces of as much as $6 \mathrm{~mm}$, those intervals are equal to corresponding spaces in much larger leaves (Fig. 9, 11, 15). This feature suggests that the small leaves are fully developed, rather than ontogenetically immature individuals; this impression finds support in the flared abscission zone evident in Fig. 6.

The secondary veins extend completely to the leaf margin with scarcely any decrease in thickness (Fig. 3, 4, 10, 11, 16). There each vein terminates precisely at the deepest point in a marginal sinus, where the vein ending coalesces with the thickened marginal border (Fig. 16). The border is slightly thicker than the vein, and the point of coalescence usually entails a slight flaring of the vein ending. The sinal termination of the secondary veins is in direct contrast to the usual condition, wherein the veins end in the marginal teeth or lobes, rather than between them; compare this with the lobal terminations shown in Fig. 13, part of a leaf

Fig. 30-36. Delnortea abbottiae (section numbers in parentheses). 30. Transverse section of petiolar vascular system and inner ground tissue. Note distinctiveness of outer (centrifugal) boundary of vascular tissues compared with internal (centripetal) boundary. Large clusters of sclerotic cells surrounded by radiating thin-walled cells present in internal ground tissue. USNM 372427 (13), $\times 22.31$. Longitudinal section of midrib, showing tracheids with evidence of scalariform-bordered secondary wall thickenings on all walls; circular-bordered pits faintly visible at right of photograph. USNM 387516 (20L8), $\times 170.32$. Transverse section of vascular tissues of midrib. Note sharp boundary between xylem (bottom) and phloem (top); poorly preserved lenticular regions in xylem represent vascular rays. USNM 387516 (17), $\times 130.33$. Transverse section of petiole, showing vascular bundle and trace (arrow) with tracheids in regular files. USNM 372427, $\times$ 26. Fig. 34, 35. Sectional views of lamina near leaf margin. USNM 387517.34. Lamina with evidence of 3 veins, probably of fourth order; dark arcs below veins and immediately adjacent to the lower epidermis are evidently sclerotic. (AI-14), $\times 65.35$. Lamina with tertiary vein. (AI-10), $\times 61.36$. Sectional view of lamina near midrib, showing sclereids (arrow) and distinct lower epidermis. USNM 372427 (14A), $\times 67$. 
of Gigantopteridium americanum (White) Koidzumi.

The tertiary veins are also regularly pinnate (Fig. 3, 7, 10). They are straight, fairly thick, and unbranched, originating from the secondaries at broadly acute but never perpendicular or obtuse angles (Fig. 3, 7, 10). The tertiaries are predominantly alternate and evenly spaced, with 8-10 veins occurring within $2 \mathrm{~cm}$ along each side of a secondary. In one specimen with unusually good preservation, a few tertiary veins are seen arising directly from the midrib (Fig. 18).

The tertiaries continue, without division, almost to the middle of the distance between adjacent secondaries; there the ends of the tertiaries abruptly diffuse into quaternary veins, whose endings coalesce with the equivalent quaternaries produced by opposing tertiaries from the adjacent secondary. This relationship apparently obtains as far as the marginal pairs of tertiaries, where some tertiaries reach very near, if not actually into, the marginal border (Fig. 7). In a few limited areas, the two opposing tertiaries nearest the margin seem to coalesce directly without diffusing into quaternaries, forming a continuous tertiary loop very near and parallel to the margin (Fig. 10, upper arrows).

Because of their uniformly close, parallel insertion and their broadly acute angulation, the opposing tertiaries form symmetrical chevronlike systems, each system delimited by the two adjacent secondary veins. Seen as aggregates of several chevron series, the tertiary veins are aptly described as a "herringbone" pattern (Fig. 3,7 ).

The quaternary or ultimate veins are seen in only a few specimens, where they appear either as impressions (Fig. 19) or as mineral stains with minute amounts of carbonaceous residue (Fig. 18). These tiny veins attain a maximum length of about $1.5 \mathrm{~mm}$ (Fig. 18), and are pinnately spaced at uniform intervals of 2-3 veins per $\mathrm{mm}$. They depart from the tertiaries at broadly acute angles approximately equal to the angulation of the tertiaries. Evidently the ultimate veins divide only rarely, except in the areas where tertiary veins arise directly from the midrib. Likewise, anastomosis is not demonstrable except where the end, or ends of an ultimate vein, merge with the ends of either an adjacent quaternary or with those of two opposing quaternaries; there are no free-ending veinlets. The resultant pattern is a simple, uniform "herringbone" or chevron-like system of very small oblong or elliptical meshes (Fig. 18, 19). Its uniformity is somewhat distorted in the intersecondary areas nearest the midrib, and in the median areas where the terminal quaternaries from adjacent and opposing tertiaries tend to be slightly larger and more randomly oriented (Fig. 19).

Despite its four orders of venation, the closed vascular pattern of Delnortea is remarkably simple and uniform, particularly in the absence of such features as sutural veins, conspicuous dichotomy in the ultimate veins, free-ending veinlets, or accessory meshes.

The reproductive organs of Delnortea are not known, but one specimen provides a basis for cautious speculation (Fig. 21). In this leaf fragment the marginal area at the right contains 3 deep, approximately hemispherical impressions, each corresponding to a marginal crenation. Their depth, definition, and positions on the leaf suggest them to be the impressions of firm globoid bodies, possibly of ovulate nature.

Anatomy, histology-Specimens described here include 1) a petiole fragment (Fig. 25, 29, 30,33 ) just proximal to the lowest part of the lamina; 2) two segments of midrib (Fig. 23, $24,26-29,31,32$ ), both relatively proximal in the lamina, one of which (Fig. 23, 26, 28, 36) contains evidence of the lamina itself; and 3) middle portions of the lamina (Fig. 34-37), including regions near the margin.

In transverse section, the petiole is approximately $9.0 \mathrm{~mm}$ wide (parallel to the plane of the lamina) and $5.0 \mathrm{~mm}$ thick (at right angle to the lamina). Portions of the midrib indicate a taper in width, from 7.4 to $9.0 \mathrm{~mm}$ wide and, in one well preserved case (Fig. 26), a thickness of $4.0 \mathrm{~mm}$. In transverse section (Fig. 26, 30), the petiole and midrib contain a cellular ground tissue similar to a stem cortex, enclosing a partial ring of vascular bundles. A heterogeneous ground tissue also bounds the vascular tissue to the inside and is confluent with the outer ground tissue adaxially on each side of the midplane of the leaf.

The lamina is attached to the midrib along a limited portion of the adaxial midrib surface adjacent to the median groove (Fig. 16, 23, 26 ). Below the base of the lamina, the groove continues as a broad, shallow depression on the adaxial surface of the petiole (Fig. 29, section 7). Where anatomically preserved, the lamina shows evidence of being entire, except at the periphery where the marginal lobes or crenations are free and partially inrolled (Fig. $15,21,37)$. Near the leaf margin, major veins, interpreted as secondary, lead directly to the sinuses between lobes (Fig. 37, arrows). The lamina shows a distinct zonation of tissues and a conspicuous difference between adaxial and 
abaxial sides (Fig. 34-36). Both lamina and midrib contain evidence of vein bundles of several different sizes (Fig. 27, 29, 33).

The outermost ground tissue of the petiole and midrib (Fig. 24, 26) consists of slightly to highly elongate, thin-walled cells. Transversely these measure from 31 to $110 \mu \mathrm{m}$ in diameter, and some show evidence of compression along radii leading to the center of the midrib (Fig. $30)$. The ground tissue contains numerous clusters of generally isodiametric cells (Fig. 24), measuring from 41 to $100 \mu \mathrm{m}$ in diameter in both transverse and longitudinal sections. These cells are better preserved than those of the surrounding tissue; many contain organic residues within their lumina, and their thick walls indicate sclerotic nature. Bounding the ground tissue to the outside is a compact tissue (Fig. 25) interpreted as a sclerified hypodermis. This tissue, several cells thick, consists of elongate cells with circular transverse outlines, 25 to $70 \mu \mathrm{m}$ in diameter. Individual cells are thickwalled, many with dark residues. The tissue in the very center of the midrib (Fig. 26, 30) is similar to the outer ground tissue, differing only in the larger size of some of the sclerotic clusters (Fig. 30), and the fact that the inner ground tissue, in transverse section, shows more radial alignment of cells, relative to the larger clusters. In the petiole, the inner ground tissue abuts the adaxial surface directly and lacks the sclerified hypodermis seen in other portions of the specimen at the same level.

The apparent abaxial and lateral limit of the vascular system is marked by a sharp boundary (Fig. 26-28, 30). In many regions, the boundary consists entirely of amorphous organic material associated with fissures. Occasionally, however, portions of an apparently specialized boundary tissue, one to three cell layers thick (Fig. 27,30), are preserved; these cells are very dark and thick-walled. In transverse section, diameters range from 30 to $90 \mu \mathrm{m}$; lengths cannot be determined with certainty. This region might be interpreted as portions of one or more bundle sheaths, since the boundary layer also occurs adaxially associated with traces (Fig. 26, 27, 29) and internally, forming a boundary between vascular and central ground tissues (Fig. 27). The boundary is most sharply defined abaxially and laterally (Fig. 26, 30), however, suggesting that, in part, it represents the limit of compression caused by centrifugal growth of the vascular tissues.

The vascular tissues of the midrib consist of tracheids in radial files (Fig. 27, 30-32), interpreted as secondary xylem, and radially aligned thin-walled cells abaxial and lateral to a distinct outer boundary of the xylem (Fig. 32), inter- preted as secondary phloem. Both xylem and phloem show evidence of limited lateral growth by means of a vascular cambium. Centripetal to the xylem is a tissue enclosed within the apparent boundary of vascular tissue, which lacks sufficient detail for characterization (Fig. $27,30)$. In transverse section the vascular tissues lie near the center of the midrib in a semicircular arc, with the open end of the arc directed adaxially. Maximum diameter of the vascular system in the petiole is $4.8 \mathrm{~mm}$, decreasing to $4.1 \mathrm{~mm}$ in one section of midrib (Fig. 29, section 18A). Individual files of tracheids regularly increase or decrease in number of elements as one counts along the perimeter of the arc, suggesting the presence of 8-10 more or less discrete collateral bundles. The phloem shows less evidence of separate vascular bundles, but lengths of files of cells and the positions of both internal and external boundaries of vascular tissue (Fig. 26, 27), support this interpretation.

The tracheids measure $20 \mu \mathrm{m}$ in diameter tangentially and $16-30 \mu \mathrm{m}$ radially, with lengths approaching $2 \mathrm{~mm}$. Secondary wall thickenings are scalariform-bordered ranging to uniseriate circular-bordered on both radial and tangential wall faces (Fig. 31). Cells interpreted as phloem elements (Fig. 32), are thin-walled and approximately the same diameter, tangentially, as adjacent tracheids. They are, however, much narrower radially, with many cells showing evidence of radial compression. In longitudinal section, very elongate thin-walled cells, with no evidence of uneven wall thickening, occur in the approximate position of the phloem. However, it is uncertain whether these represent phloem fibers, sieve cells, or poorly preserved tracheids. In both transverse and longitudinal sections, the files of tracheids are separated by narrow lenticular regions with the shape and position of vascular rays. Some (Fig. 32) of these extend into the phloem; however, individual cells are not recognizable.

The midrib supplies the lamina with vascular traces of at least two sizes. The largest traces (Fig. 27, 29, arrows), correlated with secondary veins in compressed portions of the same specimen (Fig. 23), are arcuate in section and are produced alternately by adaxial extension of the bundles at either end of the vascular arc. Each trace consists of one or possibly two vascular bundles (Fig. 27), with files of xylem and phloem elements at least partly surrounded by cells of a boundary layer like that surrounding the vascular tissues of the midrib. Upon departure (Fig. 28, 29, section 4A), each trace bends abruptly at about 90 degrees and extends laterally enclosed within a ground tis- 
sue that is histologically similar to that of the midrib. In longitudinal section (Fig. 28), all tissues of the secondary vein at the point of departure from the midrib measure $1.4 \mathrm{~mm}$ in diameter, including lamina. Smaller traces arise in the same manner from the vascular arc of the midrib; usually they are associated with traces to secondary veins (Fig. 29, 33). They consist of only about 5-10 tracheids surrounded by a transversely circular bundle sheath; these traces probably correlate with those tertiary veins that arise directly from the midrib in compression/impression surfaces. A pair of traces, somewhat intermediate in size, is observed near the base of the lamina (Fig. 29, section 7) and interpreted as traces to basal secondary veins. One (Fig. 33) contains evidence of radially aligned tracheids.

In sectional views (Fig. 34-36), the lamina has a smooth adaxial surface lacking a visible cuticle or stomata but marked by a discrete boundary with the matrix, and an undulating lower surface related to the presence of minor veins. The lamina measures from $0.3 \mathrm{~mm}$ thick between the veins, to as much as $0.75 \mathrm{~mm}$ through them. The adaxial part of the lamina consists of a compact palisade tissue ranging from $130 \mu \mathrm{m}$ to $375 \mu \mathrm{m}$ in thickness, usually consisting of a single cell layer. Individual cells are thin-walled and anticlinally elongate, averaging $44 \times 130 \mu \mathrm{m}$ in sectional views. Below the palisade, tissues are generally poorly preserved, but sclereid clusters occur in some places (Fig. 36, arrow). Some regions associated with veins (Fig. 35, 36) contain evidence of xylem elements as well as dark residues, suggesting the presence of sclereids or otherwise specialized calls of a bundle sheath or bundle sheath extension. The inrolled edges of the lamina also show evidence of sclereids, suggesting the dense marginal borders to be composed of mechanical rather than conductive tissue.

The undulating abaxial surface of the lamina is marked by a relatively well preserved, but incomplete, single layer of epidermal cells (Fig. 36); this epidermal layer is continuous with a similar layer covering at least part of the adaxial surface of the midrib (Fig. 26). Individual epidermal cells are thin-walled and very consistent in shape and size, averaging $25 \mu \mathrm{m}$ anticlinally and $31 \mu \mathrm{m}$ periclinally; stomata are not apparent.

SYSTEMATICS-Only a few fossil plant genera are known with foliar characteristics similar to those of Delnortea. These comprise the gigantopterids, a small group of mostly Permian plants with large, simple, forked, or pinnately compound leaves. Their vascularization is complex, with at least three orders of veins. The secondaries are always prominent and unbranched, but veins of the higher orders divide and coalesce to form a reticulation, with or without a sutural vein dividing the areas between adjacent secondary or tertiary veins. Leaves of this type are known only in the Northern Hemisphere, with most occurrences in Cathaysian floras. Aside from Delnortea, 4 such forms have been recorded from North America: Gigantopteridium americanum (White) Koidzumi (1936), Gigantonoclea sp. (Mamay, 1988), Cathaysiopteris yochelsonii Mamay (1986), and Zeilleropteris wattii Mamay (1986). Another related taxon remains to be described (S. H. Mamay, unpublished data).

The gigantopterids were first classified supergenerically by Koidzumi (1936), although Halle (1927) had previously published some fundamentally important descriptions. Applying the earliest name, Gigantopteris Schenk ex Potonié (Engler and Prantl, 1900, p. 511), Koidzumi described the family Gigantopteridaceae, with emphasis on observable leaf morphology and architecture and a minimum of biological speculation. Koidzumi recognized 8 genera and regarded them as "fern-like." Asama (1959) emended the Gigantopteridaceae, recognizing 14 genera. He presented a complex classification of "coherent leaf plants," based on highly theoretical evolutionary processes of lateral fusion of foliar segments ("uni-," "bi-," and "tricoherent" stages); the emended family diagnosis described the fruiting habit as “... generally the fructification of the Emplectopteris-type...."Asama subsequently produced a series of articles involving Gigantopteridaceae and stressing his theory of "Growth Retardation." In reviewing the Gigantopteridaceae, Boureau and Doubinger (1975) substantially followed the classification of Asama. Asama's ideas are, to be sure, thoughtprovoking, but as pointed out by $\mathrm{Li}$ and Yao (1983a), they are not supported by available morphologic data or stratigraphic relationships.

The most recent original work on the $G i$ gantopteris complex is the remarkable article by Li and Yao (1983b), in which two new generic names were proposed for ovulate and polleniferous organs despite the fact that both were assertedly borne on leaflets of Gigantonoclea Koidzumi. Their descriptions are unconvincing, and their concept of a single plant represented by three generic names is, of course, unacceptable. Further, their proposal of Gigantopteridales as a new ordinal name is meaningless because the taxon was not circum- 
scribed. Regardless of its undefined status, Meyen (1986) accepted Gigantopteridales as a valid taxonomic designation and included it in Group B of his proposed scheme of gymnosperm phylogeny; Meyen asserted that a close relationship between the orders Callistophytales, Caytoniales, Gigantopteridales, Ginkgoales, Leptostrobales, and Peltaspermales is "... beyond doubt. ..."

With its large, simple leaves, prominent unbranched secondaries, four vein orders and their ultimate reticulations, Delnortea obviously lies within the general circumscription of Gigantopteridaceae, in the original sense of Koidzumi (1936). The available material provides an unusually complete understanding of leaf form in Delnortea. Its salient features are remarkably consistent throughout the considerable size range of specimens, and comparisons with other gigantopterid taxa reveal in Delnortea a distinctive morphologic spectrum.

Leaf size is obviously not an important point of comparison. Foliar outlines are interesting, inasmuch as undissected simple leaves ( $\mathrm{Del}$ nortea), forked leaves (Gigantopteridium Koidzumi, Cathaysiopteris Koidzumi), and pinnately compound leaves (Gigantopteris, Cathaysiopteris), are all known in Gigantopteridaceae. In Cathaysiopteris, however, both forked and pinnately compound leaves have been noted (Mamay, 1986), so that gross leaf form may be of minor significance in the Gigantopteridaceae. A further complication lies in the fact that some descriptions have been based on small fragments with distinctive venation but unknown gross morphology. Conversely, the abundance of large Delnortea specimens, none showing any evidence of laminar division, reliably establishes the simplicity of leaf form in this plant. It is also certain that short, stout petioles with flared abscission zones were characteristic of Delnortea. Most descriptions of gigantopterid taxa omit reference to petioles, and abscission zones have not been recorded previously.

Gigantopterid margination varies among genera from entire to slightly sinuous $(\mathrm{Ca}$ thaysiopteris, Gigantopteridium), crenate ( $\mathrm{Gi}$ gantonoclea, Delnortea) or dentate (Bicoemplectopteris Asama). Although the crenations of Delnortea vary in depth and are nearly absent in the basal parts of some specimens, they are very regular in spacing and well-developed over most of the length of all leaves. The crenations of Gigantonoclea lagrelii (Halle) Koidzumi (Asama, 1959, pl. II, fig. 4, 5) are similarly uniform, but the leaf itself is pinnately compound and the veins form only three orders. Considered without regard to disposition of the secondary veins, the crenate margins of Delnortea would not be thought unusual. However, the manner in which the secondaries extend completely to the margin and terminate at the bottom of a sinus is not duplicated in any other gigantopterid. The secondary veins of all other taxa become diffuse or obscure before reaching the margin, or they extend into the tip of a lobe. The indurated border is also unknown among other gigantopterids. Sinal termination and fusion of the secondaries with the marginal border thus uniquely characterize Delnortea.

Delnortea is easily recognized on the basis of even a small segment of leaf margin with secondary veins preserved, but attention must focus on details of the finer venation because of the wide variability of vein patterns shown by the gigantopterids. Some genera (Cathaysiopteris, Gigantopteridium) have only three orders of veins, while others have four (Bicoemplectopteris, Zeilleropteris Koidzumi) or five (Gigantopteris, Tricoemplectopteris Asa$\mathrm{ma})$. The venation of Gigantopteris is singular in that the tertiary and quaternary veins form irregular areoles, each containing several freeending veinlets. This is best seen in $G$. dictyophylloides $\mathrm{Gu}$ et Zhi (1974, pl. 102, fig. 6), where the areolation and ultimate vein configuration are remarkably similar to those of $G n e$ tum or a dicotyledonous leaf. Tricoemplectopteris, with just one species, $T$. taiyuanensis Asama (1959), merits mention because its venation also seems to form a five-ordered pattern. Asama's description is based on one fragment, first illustrated by Halle (1927, pl. 43, 44, fig. 9) as Gigantopteris nicotianaefolia. Dimensions of the specimen indicate a leaf with an extraordinarily broad undissected lamina; unfortunately, the apparently poor preservation precludes a satisfactory analysis of the penultimate and ultimate vein patterns.

The remaining notable feature of gigantopterid venation lies in the sutural veins, which occur between and parallel to adjacent secondary and tertiary veins. These appear in $\mathrm{Ca}$ thaysiopteris, Gigantopteridium, and Zeilleropteris, but are absent in Delnortea. Lacking both sutural veins and free-ending veinlets, then, the only taxon with which Delnortea might be confused is Gigantonoclea hallei (Asama) Gu et Zhi, 1974.

Gigantonoclea hallei was based on a number of specimens from the Permian of China, first described as Gigantopteris nicotianaefolia by Halle (1927) and later assigned to Bicoemplectopteris (B. hallei Asama, 1959). These specimens together show a large, pinnately compound leaf with acutely dentate margins 
and secondary veins terminating in the tips of the teeth. These features alone distinguish $G$. hallei from Delnortea, but if only a partial leaflet of $G$. hallei, were available the distinction might prove more difficult. Nonetheless, the single specimen in which the finer venation can be satisfactorily seen (Halle, 1927, pl. 45, fig. 5) differs from Delnortea in the following details: in $G$. hallei the tertiaries are much finer relative to the secondaries, the differentiation between tertiaries and quaternaries is much less pronounced, the meshes are more profuse and more randomly oriented, and a line of much-elongated meshes ("accessory meshes" of $\mathrm{Li}$ and Yao, 1983a) lies against each side of the secondaries.

In most features Delnortea is distinct from any other taxon heretofore assigned to the $\mathrm{Gi}$ gantopteridaceae, whether one follows the original system of Koidzumi, which we prefer, or the revised arrangement proposed by Asama. The most apparent difference is in the margin-secondary vein relationship. The other distinctions, although less obvious, contribute cumulatively to the individuality of Delnortea among those genera, which are treated as taxonomically allied almost solely on the basis of their strong secondary veins and reticulate subsidiary venation. However, there is no apparent morphologic basis for distinguishing species in Delnortea; accordingly, we presented a combined generic-specific diagnosis in our protologue (1986). The diagnosis is repeated here, with minor modifications:

Amplified combined diagnosis-Delnortea abbottiae Mamay, Miller, Rohr, and Stein, 1986: Leaves simple, petiolate, from 1.2 to an estimated $35.0 \mathrm{~cm}$ long, 0.8 to $8.5 \mathrm{~cm}$ wide. Petioles short ( 4.0 to $22.0 \mathrm{~mm}$ long), thick (to $1.0 \mathrm{~cm}$ wide), with a flaring abscission zone. Laminae symmetrical, flat or vaulted, with slightly revolute margins and a median groove on the adaxial surface; outlines orbiculate to oblong, elliptical or linear; tips acute to rounded; bases acute, rarely obtuse; margins shallowly to deeply crenate, rarely entire near the laminar base, demarcated by a narrow, uninterrupted border of indurated tissue, partly sclerified. Adaxial surfaces smooth, abaxial surfaces undulate; epidermal cells thin-walled, $25 \times 30 \mu \mathrm{m}$ in anticlinal section; palisade layer 130-375 $\mu \mathrm{m}$ thick, with anticlinally elongate cells to $130 \mu \mathrm{m}$ high.

Veins pinnate, in four orders. Primary vein (midrib) straight, stout (to $9.0 \mathrm{~mm}$ wide), subterete in section, narrowly attached to the abaxial surface of the lamina beneath the median groove. Secondary veins strong, parallel, evenly spaced to $1.5 \mathrm{~cm}$ apart, alternate to opposite, unbranched, acute, perpendicular or slightly obtuse, each terminating at a marginal sinus and merging into the indurated laminar border. Tertiary veins strong, straight, parallel, broadly acute, numerous (less than $3.0 \mathrm{~mm}$ apart), a few arising directly from the midrib between adjacent secondaries; tertiaries with diffuse endings merging with those of opposing tertiaries from the adjacent secondary; tertiaries and secondaries together forming a regular, rigid "herringbone" pattern. Quaternary veins fine, numerous, acute, dividing very sparsely; all ultimate vein endings coalescing with others, forming a dense network of small oblong meshes, directed forward at broadly acute angles.

Petiole and midrib with a heterogeneous ground tissue consisting of variously elongate undifferentiated cells $30-110 \mu \mathrm{m}$ in diameter, clusters of isodiametric sclereids $40-100 \mu \mathrm{m}$ in diameter, a sclerified hypodermis consisting of elongate, transversely circular thick-walled cells $25-70 \mu \mathrm{m}$ in diameter, and a vascular system consisting of an adaxially open, semicircular arc of 8 to 10 variably discrete collateral bundles, the arc enclosed by a discrete boundary tissue. Both xylem and phloem elements occurring in regular radial files separated by narrow lenticular vascular rays. Tracheids 16 to $30 \mu \mathrm{m}$ in diameter; secondary wall sculpturing ranging from scalariform-bordered to uniseriate circular-bordered pits on all walls. Traces from midrib enclosed by a sclerified bundle sheath, arising from adaxial bundles of the vascular arc; the largest traces narrow, arcuate in section, supplying the secondary veins; smaller traces terete in section, supplying the tertiary and quaternary veins.

Holotype: USNM 364416 (Fig. 1 A, Mamay et al., 1986; Fig. 16, this paper).

Other illustrated specimens: USNM $364417-$ $420 ; 372427$; 387469-474; 387476-478; $387480-481 ; 387516-517$. These specimens were available and used in the preparation of the protologue (Mamay et al., 1986), but were not given type status. We regard them as practical equivalents to formal paratypes.

Geographic occurrence: Del Norte Mountains, Brewster County, Texas; $1.7 \mathrm{~km}$ south of Bird Mountain summit, approximately 30 $\mathrm{km}$ southeast of Alpine.

Stratigraphic occurrence: Road Canyon Formation, uppermost part of Leonardian Series; Lower Permian.

Derivation of names: The generic name refers to the Del Norte Mountains. The specific name acknowledges the assistance and friendship of our late colleague, Maxine L. Abbott. 
DisCussion-Morphological and phylogenetic interpretations - The large range in leaf size is a most curious aspect of the Delnortea collection. Ordinarily this would likely be interpreted as an assortment of juvenile and mature leaves, but the consistently wide spacing and apparent maturity of the secondary veins in even the smallest specimens suggest that these are fully developed appendages. The fact that all sizes have flared abscission zones and little indication of gradual deterioration by withering, decay or detrition, suggests that all leaves were shed at about the same time and at the same stage of development-i.e., at maturity. Approximately simultaneous defoliation almost certainly explains the presence of leaves of all sizes on the same bedding plane; it may also be indicative of pronounced seasonality. The relative positions of large and small leaves on a given plant are not known, but it is possible that the smallest were the first to unfold and were homologues of bud scales.

The nature of reproduction in Delnortea is only hinted at by one specimen (Fig. 21); the oval depressions may represent a group of large seeds near the margin of the leaf, as in Spermopteris. A large production of large seeds could demand a greater nutritive supply and result in a well-vascularized and mechanically strong petiole and midrib in the fertile leaf. The unusually strong midribs of some specimens (Fig. 23) might be explained that way.

Without real evidence regarding reproductive organs, conclusions as to the botanical affinities of Delnortea are limited to the foliar morphology and internal anatomical features. The overall appearance of the leaf is spectacular in its precise and complex organization, which suggests a precocious evolutionary status attained rather in advance of most of its Paleozoic associates. Each of its more notable qualitative characteristics is approximated or duplicated in the ferns or higher vascular plants, but the combination of its known vegetative characteristics provides the main basis for an approach to the taxonomic appraisal of $\mathrm{Del}$ nortea.

Of primary importance is the vascular system of the petiole and midrib; there the welldeveloped, seriated secondary xylem and phloem are clearly the products of a bifacial vascular cambium. Although this growth mechanism is characteristic of the seed plants, it is also known in lower groups. According to Taylor (1981, p. 180), Sphenophyllum is "... the only nonseed plant that produced secondary xylem and phloem from a bifacial cambium ...," while Stewart (1983, p. 221) states that "... the vascular cambium of Tetraxy- lopteris and all other progymnosperms is bifacial. ..." Those examples of independent development of the vascular cambium need no further discussion, because the megaphyllous laminar morphology, closed venation, and secondary vascular tissues of Delnortea constitute an aggregate of characters not known in any plant group below the taxonomic level of the pteridosperms. Because of limited permineralized material and marginal preservation, some important details are not available for use in determining whether the wood is manoor pycynoxylic. However, the available anatomical sections reveal a fairly compact wood, and whether manoxylic or pycnoxylic, this anatomy clearly indicates gymnospermous affinity for Delnortea. We suggest that the taxonomic position of Delnortea lies somewhere within the broad limits of the pteridosperms, as circumscribed by Taylor (1981).

The semicircular configuration of the vascular system of the petiole and midrib is not in itself definitive, because this is a generalized form of leaf trace, common among ferns, gymnosperms, and angiosperms. Nevertheless $\mathrm{Del}$ nortea is distinct by virtue of the abundant secondary tissue in the trace and its dissection into irregularly shaped bundles (Fig. 29). In cross section the leaf vascularization of $\mathrm{Cal}$ listophyton, by contrast, is a narrow, undissected, shallowly arched band with continuous secondary xylem covering the abaxial side; the secondary xylem is rarely divided into two adjacent strands (Rothwell, 1975), but the trace itself remains undissected. An opposite extreme in seed fern leaf-trace anatomy is seen in Medullosa, where the petiolar vasculature consists of many scattered bundles with no secondary tissue. Among other seed ferns one might be tempted to regard the central vascular reticulum of a Glossopteris leaf, with its secondary tissues (Gould and Delevoryas, 1977), as a flattened version of the arcuate trace of Delnortea. Implications of this and the foregoing comparisons are remote and involve only a small part of the respective leaves; to infer close relationship on those grounds would be inconsistent with the major differences in venation patterns.

Two extravascular features of Delnorteasclerosis and vernation - are available for assessment. Aggregates of sclerotic cells are moderately abundant in the ground tissue of $\mathrm{Del}$ nortea, and their presence may reflect affinity with the Pennsylvanian seed ferns, in which sclerotic nests, strands, or plates are conspicuous. Conversely, the foliar vernation of $\mathrm{Del}$ nortea would appear to represent a morphologic disparity with the ferns and pteridosperms. 
Excepting Ophioglossales, the leaves of all modern ferns are characterized by circinate vernation. This feature has been noted in some of the Paleozoic seed ferns and is particularly well known in Callistophyton, where each pinna of the decompound frond terminates in a crozier (Rothwell, 1975). By contrast, Delnortea shows no indication of circinate vernation. The hypodigm includes very small leaves (Fig. $5)$ as well as very large ones (Fig. 10); the distal parts of many specimens are complete, and all are flat. Thus it is probable that Delnortea produced its leaves through unmodified, erect vernation. While this might appear to weaken a case for phylogenetic alliance of Delnortea with the seed ferns or for a fernlike ancestry, it should be kept in mind that circinate vernation does not characterize all ferns, nor are the majority of pteridosperms known one way or another.

These comparisons are, of course, inconclusive as to the taxonomic position of Delnortea within the gymnosperms. Consequently, we affirm Mamay's (1986) assignment of Delnortea to Gigantopteridaceae, in the original sense of Koidzumi (1936). We recognize that vegetative variability may reflect reproductive differences demanding of future taxonomic revision of that family. We regard the reports by Asama (1959) and $\mathrm{Li}$ and Yao (1983b) of gigantopterid ovulifery as unsubstantiated, and pending more credible reports of attached reproductive parts, we suggest caution in interpreting the biological significance of any system of gigantopterid classification.

Morphological assessment of the American gigantopterids indicates a decidedly advanced level for Delnortea; this is consistent with the relative ages of the 4 other taxa (Cathaysiopteris yochelsoni, Gigantonoclea sp., Gigantopteridium americanum, and Zeilleropteris wattii), all of which are older than Delnortea (Fig. 2). The primitive aspect of dichotomy is absent in Delnortea, and we regard this the principal basis for evaluation. In C. yochelsoni, $G$. americanum, and $Z$. wattii the midrib and lamina are forked, whereas those of Delnortea are simple; because the general architecture and lower vein orders are unknown in the Texas Gigantonoclea, that taxon cannot enter into this evaluation. With the possible exception of Gigantonoclea, the secondary veins of all the American taxa are simple. However, the tertiaries of Delnortea and Zeilleropteris are simple, but those of Gigantopteridium and $\mathrm{Ca}$ thaysiopteris show varying incidence of dichotomy and anastomosis, while the ultimate veins of Gigantonoclea form a dense meshwork with little evidence of dichotomy. Although Delnortea and Zeilleropteris both have quaternary veins, Delnortea has no sutural veins, which appear only in those taxa with forked laminae and midribs. Gigantonoclea also lacks sutural veins, but its profusely reticulate ultimate venation does not show the well-ordered precision of the quaternary reticulation of Delnortea.

Other conspicuous attributes of Delnortea that invite attention are the petiole base, the marginal border of the lamina, and the sinal termination of the secondary veins. The flared and neatly truncated petiole base appears to be a normal feature of the plant, and suggests a deciduous habit. Abscission is well known in some fossil plants, particularly the Paleozoic lycopods, but Delnortea presents the only known indication of that specialization among the gigantopterids.

Thickened marginal borders similar to that of Delnortea are known elsewhere in the fossil record, particularly in the Mesozoic genera Madygenia, Lomatopteris, and Pachypteris; their function has not been determined, however, beyond the suggestion that they were related to the presence of reproductive organs (Boureau and Doubinger, 1975, p. 264). The resemblance to an indusiate marginal fern sorus is noted, but there is no evidence of sporangia or a completely involute leaf margin in Delnortea. The presence there of sclereids suggests a mechanical tissue, but the possibility of vascularization cannot be discounted. If vascular, the thickened margin of Delnortea could represent an early morphological equivalent of the angiopsermous fimbrial vein or the continuous marginal vein of Marsilea.

The singularity of the Delnortea leaf finds emphasis in the sinal termination of its secondary veins. This character appears infrequently in Gigantopteridium americanum, where the secondaries normally end in the tips of the lobes (Fig. 13). Otherwise, no other gigantopterid shares this feature. Indeed, it is the "rule" in leaves of all groups that marginal lobes or teeth each receive a vein; Delnortea is a rare exception. If one subscribes to the theory of lateral fusion of adjacent pinnae as proposed by Asama (1959), one can visualize the evolution of the Delnortea leaf with its inverse sinus-vein arrangement - provided that the ancestral pinnae were retuse. Then the secondary veins and marginal sinuses of Delnortea would represent the midribs and retusions of the fusing pinnae; however, such an evolutionary process is not supported by any evidence.

Whatever evolutionary steps may have been involved in this modification, the result has been duplicated elsewhere. We are aware of 
one other example, which interestingly enough, appears in the extant angiosperm Nothofagus. In his treatment of Papuan Nothofagus, Steenis (1953, Fig. 3) illustrated the venation patterns of 22 species, most of which have normal vein configurations. In $N$. pumilio, however, the margin is doubly crenate, with a secondary vein ending at the bottom of every other sinus. The resemblance to Delnortea is closer in $N$. gunnii, where the crenations are very uniform and regularly spaced, with each sinus receiving a secondary vein. Steenis $(1953$, p. 332$)$ regarded $N$. gunnii as a "... taxonomically remote species ...," without elaboration. Aguirre and Romero (1982) also illustrated N. gunnii, commenting on the distinctiveness of its regular crenations and sinally directed secondary veins. Here, as in Delnortea, the sinus-vein arrangement appears as an anomaly.

Gnetum-like aspects of Delnortea-The foregoing aggregate of characters distinctly isolates Delnortea as a plant with highly modified leaves, whose presence in the Paleozoic seems to reflect an unusually vigorous and innovative genetic lineage. In view of our vast knowledge of Pennsylvanian floras and our somewhat more limited understanding of floras of the Wolfcampian Permian, one might hope to encounter some clue as to the origin of Delnortea. Unfortunately, such is not the case. Delnortea represents a radical departure from the stereotypification of, for example, the pecopterids, neuropterids and other ubiquitous Paleozoic groups; for the time being, however, the matter of its origin must remain a mystery.

Conversely, the evidence in Delnortea of dramatic and rapid evolution engenders the intriguing thought that a derivative of the $\mathrm{Del}$ nortea lineage may be discernible in a younger fossil or an extant plant. As a broadleaved gymnosperm with pinnate-reticulate venation and short petioles with enlarged bases, the living genus Gnetum compares more closely with Delnortea than does any other plant, living or fossil. The engimatic Triassic Furcula, with its reticulate venation, might conceivably be included in these comparisons, but we regard this as an improbable concept because of the dicotlike cuticle and dichotomous architecture of Furcula leaves.

Much literature regarding gymnosperm evolution has accumulated, with a large proportion devoted to the conifers; Meyen $(1984,1986)$ reviewed much of that information. The gnetophytes are often mentioned, but discussions are usually brief. Gnetum figures prominently in theoretical discussions of the origin of the angiosperms (Crane, 1985; Doyle and Donoghue, 1986), however, because of its dicot-like leaves and the vessels in its secondary xylem. In reference to the leaves, Stewart (1983, p. 382 ) recently wrote: "Of all leaf types belonging to gymnosperms, those of Recent Gnetum most closely approximate angiosperm leaf venation patterns." Earlier, Duthie (1912, p. 599) stated ". . . the reticulate venation of the Gnetum leaf is of the normal dicotyledonous type. ..." A more definitive assessment is that of Pearson $(1929$, p. 32), who wrote: "The primary nerves, five on each side in $G$. africanum, give rise to submarginal loops, and their ultimate branches form a network with blind endings, which is a truly angiospermous character." The angiospermlike vessels in the secondary xylem of Gnetum generate similar discussions, but with much less agreement; opinions vary on the phylogenetic implications of finer details of vessel wall structure. Muhammad and Sattler (1982) reviewed some of the conflicting opinions on wood anatomy and other angiospermlike features in Gnetum, cautiously suggesting that Gnetum may have been ". . . close to the ancestry of all or at least some of the taxa of angiosperms. ..."

The ancestry of Gnetum is likewise a highly conjectural matter, enlightened by very little fossil evidence. Many occurrences of Mesozoic pollen resembling that of modern gnetophytes have been reported (Brenner, 1976; Trevisan, 1980 ), but megafossil evidence is limited to the recently described taxon Drewria potomacensis (Crane and Upchurch, 1987) of Early Cretaceous age. Most attempts to establish relationships of Gnetum involve the older Mesozoic floras, and relate Gnetum to the bennettitaleans. This concept is based largely on characters of the cones and seeds; it seems to be the commonly preferred one (Maheshwari and Vasil, 1961; Martens, 1971). Little importance has been attached to leaf characters, nor have Paleozoic plants attracted significant attention. Only Schopf (1976, p. 59) addressed the possibility of a Paleozic origin for Gnetum, hinting at a relationship between the glossopterids and gnetophytes. Such a relationship is not impressively supported by comparative leaf architecture, and Schopf did not appear to be enthusiastically espousing the idea.

In light of the inadequacy of factual material that might assist in identifying descendants of Delnortea and other gigantopterids, Gnetum offers a welcome avenue for deductive comparisons. Concomitantly, Delnortea provides a source of certain of the physical attributes of Gnetum; the two oddities complement each other in a manner rarely observed between two 
taxa as distantly separated in geologic time. It is interesting indeed that Doyle and Donoghue (1986), in considering the origin of anthophytic leaves, suggested that derivation of angiosperms and Gnetum from taeniopterid ancestors "... would involve no change in major venation, only origin of reticulation and interpolation of new vein orders...." In Delnortea we recognize an embodiment of not only the major venation diagrammed in their hypothetical common ancestral leaf, but also of the very characters invoked in theory by Doyle and Donoghue.

While both theoretical and factual arguments for a Delnortea-Gnetum relationship are impressive, differences exist in ultimate venation and anatomical details. The dicot-like aspect of Gnetum venation is well illustrated in Duthie's (1912, pl. 57, fig. 6, 7) article on $G$. africanum. This consists of an areolate system apparently equivalent to the 'imperfect' stage (Hickey, 1979, fig. 118), with many blindending ultimate veins. This feature does not appear in Delnortea, where all the ultimate veins coalesce with others, forming tiny meshes. It is significant, however, that two other gigantopterids, from the Permian and Triassic of China, have areolate vein patterns. Gigantopteris nicotianaefolia Schenk, emend Gu et Zhi (1974, fig. 103-105), the older of the two, is restricted to the late Early Permian and early Late Permian (Li and Yao, 1980); its venation is reminiscent of the "incomplete" stage of areolation (Hickey, 1979, fig. 117), but blind endings are only obscurely seen. In $G$. dictyophylloides Gu et Zhi (1974, fig. 103, 104), whose range apparently extends into the Early Triassic, the areolation is more organized, approximating the "imperfect" stage (Hickey, 1979, fig. 118). Moreover, the extent of its areoles and distribution of its distinct blind-ending veinlets are startlingly similar to Gnetum or to any number of dicotyledons, but $\mathrm{Li}$ and $\mathrm{Yao}$ (1983a) indicated a possible but questionable relationship between $G$. dictyophylloides and Furcula. G. dictyophylloides obviously was named in allusion to the venation of the Jurassic fern Dictyophyllum. That apt comparison emphasizes the fact that areolate, blindending venation is not restricted to the angiosperms, but is known among the ferns as well. However, comparative vascular anatomy discourages a fern-like interpretation for at least Delnortea.

Although anatomical comparisons are limited to the petiole and midrib, some similarities are demonstrable between Delnortea and Gnetum. As illustrated by Maheshwari and Vasil (1961, fig. 23, 24), the midribs of Gnetum gne- mon and G. ula each contain a shallowly arcuate vascular system with secondary tissues. In older leaves of $G$. gnemon the arc is divided into several discrete bundles, but in $G$. ula the dissection is apparently incomplete, as in $\mathrm{Del}$ nortea. Another resemblance lies in the association of sclerotic cells with the vascular arc in both genera. The most evident difference appears in the tracheids of Delnortea versus the vessels of Gnetum. The significance of that characteristic has been widely debated in the past, but the consensus seems to have stabilized in the admission that the vessels of Gnetum are ascribable to "... a remarkable example of convergent evolution ..." (Sporne, 1965, p. 173) or “... le résultat d'une évolution parallèle ou convergente ..." (Martens, 1971 , p. 254). In this context, we choose to accept the vessels of Gnetum as an anomalous, but not insurmountable, barrier to a relationship between Delnortea and Gnetum. Considered as a single character, the vessels of Gnetum need indeed make it no more distantly related to Delnortea than to any other gymnosperm.

Floristics, biostratigraphy, and phytogeography - The significance of Delnortea extends considerably beyond taxonomy and evolutionary theorization. Some accessory implications are preliminarily introduced here.

A major consequence of this study is its involvement in current reassessments of the " $G i$ gantopteris flora" of North America (Mamay, 1986). That concept assumes a new dimension with the recognition of the Cathaysian genera Gigantonoclea, Cathaysiopteris, and Zeilleropteris in Texas, and the rejection of the true Gigantopteris. Thus the American "Gigantopteris flora" is, for the present, more aptly referred to as a "Gigantopteris flora without $G i$ gantopteris." With the addition of Delnortea, the gigantopterids now include 5 genera instead of the previously misidentified one (the $G i$ gantopteris of Read and Mamay, 1964); yet undescribed Texas material will contribute at least one generic addition (Mamay, unpublished data). The "older Gigantopteris flora" of Read and Mamay may now be known as the "Gigantopteridium flora," while their "younger Gigantopteris flora" may be termed the "Cathaysiopteris flora." Inasmuch as Delnortea is geologically younger than the related taxa, the ultimate recognition of a third distinct flora seems likely.

The physical characteristics of Delnortea render it a potentially useful biostratigraphic tool that eventually may be applied toward a redefinition of the Permian floral zonation of Read and Mamay (1964). Another practical 
aspect of the Delnortea occurrence lies in its applicability toward at least one geographically restricted area where interpretation of depositional environments is industrially important; this is the petroliferous Permian Basin. Many geologists (e.g., Cys and Mazullo, 1978) consider the western facies of the upper Leonard rocks of the Del Norte Mountains to represent deeper-water clastics bordering on the Hovey Channel. This interpretation would place the Delnortea site in a deep basin. The Delnortea beds, however, represent a shallow deltaic setting, clearly in conflict with a basinal version of sedimentation.

The Read and Mamay (1964) concepts of floral differentiation and provinciality seem to be not only supported but enhanced by the impressive variety of gigantopterids now known in Texas. The provinciality of the American gigantopterids is notable in that their geographic distribution is contained within an area approximately $800 \mathrm{~km}$ wide; stratigraphically they are limited to the Leonard Series. Even more remarkable is the fact that 4 of these generaCathaysiopteris, Gigantonoclea, Gigantopteridium, and Zeilleropteris - are known from sites no more than $30 \mathrm{~km}$ from each other, where they co-occur with 2 other distinct but yet enigmatic genera (Russellites and Wattia), as well as the pteridosperm Tinsleya.

With the recognition of Cathaysiopteris, $G i$ gantonoclea, and Zeilleropteris in Texas, the similarity between the American and Cathaysian floras becomes more impressive than previously thought, even though the 2 most distinctive genera-Gigantopteris and Delnorteaoccur only in Asia and America, respectively. However, the presence of Russellites in both floras injects an even more emphatic taxonomic identity into these comparisons: material that is not distinguishable from Russellites taeniata (Darrah) Mamay (1968) has been found in Shanxi Province, China, and described under the name Yuania chinensis (Du and $\mathrm{Zhu}$, 1982). Thus Mamay's earlier opinion (Mamay, 1968 , p. 112) that ". . . the similarities between the American and Asiatic members of that complex are more apparent than real, and therefore are misleading from the standpoint of transoceanic paleofloristic linkages"... is no longer tenable; the similarities are, indeed, real. They are so real, in fact, as to extend beyond the imaginable influences of parallelism, and effectively dispel the notion expressed by Asama (1976, p. 205) that "... the floral similarity between the two regions should be ascribed to parallelism rather than migration. ..."

The subjects of plant dispersal and distri- bution have evoked many detailed discourses. Some contrastingly simplistic views may be refreshingly provocative, if not necessarily conclusive.

In his treatment of Gigantopteris americana-now known as Gigantopteridium americanum-White (1912) discussed geographic distribution of Gigantopteris with emphasis on migration routes; he concluded that "... the distinctly Chinese types must have come to Texas and Oklahoma by the north Pacific (Alaskan) route...." Later, Mamay (1960) aired the opposing view that “. . . Plant migration between North America and Asia is thus suggested, with the southwestern United States a likely point of origin. ..." Assessment of the facts of geographic distribution seems to favor Mamay's ideas.

As demonstrated by Chaloner and Meyen (1973) and Li and Yao (1980), the Cathaysian floras occupy a vast area that includes much of southern and central China and southeastern Asia, with a few occurrences of Gigantopteris in North China and one in Turkey. This is in great contrast with the limited geographic range of the American flora. Yet it is clear that the two floras are closely related and that one was probably derived from the other. To explain the concentration of gigantopterids in Texas by migration from Asia would necessitate a "funneling" effect, by which very widely dispersed elements were condensed into a very small area. The alternative explanation finds support in the evidence, contained in the innovative characteristics of Delnortea and some of its associates, of vigorous evolutional traits that rapidly produced ecologically adaptable and geographically venturesome forms capable of quickly expanding their domain. Yet another thought appears to bolster these impressions. The leaves of the American gigantopterids are predominantly forked or simple; none is compound (Mamay, 1986). On the other hand, the Asiatic gigantopterids are predominantly simple or pinnately compound. This seems to express a tendency, among the Asiatic forms, toward abandonment of the archaically dichotomous leaf form, implying derivative status and younger age.

Whatever credibility the foregoing notions may merit, their exposition can only embellish the reality that the southwestern United States contained a singularly important center of Permian plant evolution and that the Leonardian rocks represent the correspondingly important time interval (Mamay, 1976). Delnortea represents the most recently discovered expression of the evolutionary influences exerted in that place and time. 


\section{LITERATURE CITED}

Aguirre, A. C., AND E. J. Romero. 1982. Arquitectura foliar de las especies Australianas y Neocelandesas de Nothofagus (Fagaceae). Bol. Soc. Argent. Bot. 20(34): $227-240$.

Albritton, C. C., JR., AND J. F. Smith, JR. 1965. Geology of the Sierra Blanca area, Hudspeth County, Texas. U.S. Geol. Survey Prof. Paper 479: 1-131.

Asama, Kazuo. 1959. Systematic study of so-called $G i$ gantopteris. Tohoko Univ. Sci. Repr., Geol. 31: 1-72.

- 1976. Gigantopteris flora is Southeast Asia and its phytopaleogeographic significance. Geology \& Palaeont. Southeast Asia 17: 191-207.

Boureau, E., AND J. Doubinger. 1975. Pteridophylla (Prem. part.) Traité de paléobotanique 4: 378-426.

BRENNER, G. J. 1976. Middle Cretaceous floral provinces and early migrations of angiosperms. In C. B. Beck [ed.], Origin and early evolution of angiosperms, 2347. Columbia University Press, New York.

Chaloner, W. G., and S. V. Meyen. 1973. Carboniferous and Permian floras of the northern continents. In A. Hallam [ed.], Atlas of palaeobiogeography, 169 186. Elsevier, Amsterdam.

Cooper, G. A., and R. E. Grant. 1972. Permian brachiopods of West Texas. 1. Smithsonian Contr. Paleobiology 14: 1-231.

Crane, P. R. 1985. Phylogenetic analysis of seed plants and the origin of angiosperms. Ann. Missouri Bot. Gard. 72: 716-793.

$\longrightarrow$, AND G. R. UPChURCh, JR. 1987. Drewria potomacensis, gen. et sp. nov., an early Cretaceous member of Gnetales from the Potamac group of Virginia. Amer. J. Bot. 74: 1722-1736.

Cys, J. M., AND S. J. Mazzullo. 1978. Lithofacies and sedimentation of Lower Permian carbonates of the Leonard Mountain area, Glass Mountains, western Texas: a discussion. J. Sed. Pet. 48: 1363-1368.

Doyle, J. A., AND M. J. Donoghue. 1986. Seed plant phylogeny and the origin of angiopserms: an experimental cladistic approach. Bot. Rev. 52: 321-431.

Du, Xianming, And Jianan Zhu. 1982. The emendation of a cycad genus Yuania and the discovery of $Y$. chinensis sp. nov. Mem. Beijing Natl. Hist. Mus. 17: 1-6.

Dunbar, C. O., AND Others. 1960. Correlation of the Permian formations of North America. Bull. Geol. Soc. Amer. 71: 1763-1806.

Duthie, A. V. 1912. Anatomy of Gnetum africanum. Ann. Bot. 26: 593-602.

Engler, A., AND K. Prantl. 1900. Die natürlichen Pflanzenfamilien: pt. 1, abt. 4: 1-808. Leipzig.

Gould, R. E., AND T. Delevoryas. 1977. The biology of Glossopteris: evidence from petrified seed-bearing and pollen-bearing organs. Alcheringa 1: 387-399.

Halle, T. G. 1927. Palaeozoic plants from central Shansi. Geol. Survey China, Palaeontologia Sinica, Ser. A, 2: $1-316$.

HiCKEY, L. J. 1979. A revised classification of the architecture of dicotyledonous leaves. In C. R. Metcalfe and L. Chalk [eds.], Anatomy of the dicotyledons, 2d ed., Vol. 1, 25-39. Clarendon, Oxford.

Institute of Geology and Palaeontology, ACademia Sinica and Institute of Botany, ACademia Sinica [Gu and Zhi,eds.]. 1974. Paleozoic plants from China. Science Press, Beijing [in Chinese].

KING, P. B. 1931. The geology of the Glass Mountains, Texas, Part 1: descriptive geology. Univ. Texas Bull. 3038: $1-167$.
KING, R. E. 1931. The geology of the Glass Mountains, Texas, Part 2: faunal summary and correlation of the Permian formations with description of Brachiopoda. Univ. Texas Bull. 3042: 1-245.

KoIDzumi, G. 1936. Gigantopteris. Acta Phytotaxonomica et Geobotanica 5: 130-144.

Li, Xingxue, and Zhaoqi Yao. 1980. An outline of recent researches on the Cathaysia flora in Asia. Institute Geol. \& Paleont., Acad. Sinica.

$\longrightarrow$, AND - 1983a. Current studies of gigantopterids. Palaeontologia Cathayana 1: 319-326.

- - AND —. 1983b. Fructifications of gigantopterids from South China. Palaeontographica 185B: 11-26.

Maheshwari, P., AND V. VAsil. 1961. Gnetum. Council of Scientific \& Industrial Research: Botanical Monograph No. 1. New Delhi.

Mamay, S. H. 1960. Gigantopteridaceae in Permian floras of the southwestern United States. U.S. Geol. Survey Prof. Paper 400-B: B380.

__ 1967. Lower Permian plants from the Arroyo Formation in Baylor County, north-central Texas. U.S. Geol. Survey Prof. Paper 575-C: C120-C126.

- 1968. Russellites, new genus, a problematical plant from the Lower Permian of Texas. U.S. Geol. Survey Prof. Paper 593-I: I1-I16.

- 1976. Paleozoic origin of the cycads. U.S. Geol. Survey Prof. Paper 934.

- 1986. New species of Gigantopteridaceae from the Lower Permian of Texas. Phytologia 61:311-315.

- 1988. Gigantonoclea in the Permian of Texas. Phytologia 64: 330-332.

, J. M. Miller, AND D. M. Rohr. 1984. Late Leonardian plants from West Texas: the youngest $\mathrm{Pa}$ leozoic plant megafossils in North America. Science 223: 279-281.

1986. Delnortea, a new genus of Permian plants from West Texas. Phytologia 60: 345-346.

$\longrightarrow$, AND B.L. ReED. 1984. Permian plant megafossils from the conglomerate of Moun Dall, central Alaska Range. The United States Geological Survey in Alaska: accomplishments during 1981. U.S. Geol. Survey Circ. 868: 98-102.

Martens, P. 1971. Les gnétophytes. Gebrüder Borntraeger, Berlin.

Meyen, S. V. 1984. Basic features of gymnosperm systematics and phylogeny as evidenced by the fossil record. Bot. Rev. 50: 1-111.

—. 1986. Gymnosperm systematics and phylogeny; a reply to commentaries by C. B. Beck, C. N. Miller, and G. W. Rothwell. Bot. Rev. 52: 30-320.

Miller, C. N., AND J. T. BrowN. 1973. A new voltzialean cone bearing seeds with embryos from the Permian of Texas. Amer. J. Bot. 60: 561-569.

Muhammad, A. F., AND R. SatTler. 1982. Vessel structure of Gnetum and the origin of angiosperms. Amer. J. Bot. 69: 1004-1021.

Olson, E. C. 1958. Fauna of the Vale and Choza: 14. Summary, review, and integration of the geology and the faunas. Fieldiana: Geology 10: 397-448.

Pearson, H. H. W. 1929. Gnetales. Cambridge University Press, Cambridge.

Read, C. B., ANd S. H. Mamay. 1964. Upper Paleozoic floral zones and floral provinces of the United States (including Glossary of stratigraphic terms, by Grace Keroher): U.S. Geol. Survey Prof. Paper 454-K: K1K35. 
Rothwell, G. W. 1975. The Callistophytaceae (Pteridospermopsida), part I: vegetative structures. Palaeontographica B151: 171-196.

SCHOPF, J. M. 1976. Morphologic interpretation of fertile structures in glossopterid gymnosperms. Rev. Palaeobot. Palynol. 21: 25-64.

SPORNE, K. R. 1965. The morphology of gymnosperms. Hutchinson University Library, London.

SteEnis, C. G. G. J. van. 1953. Results of the Archbold Expedition: Papuan Nothofagus. J. Arnold Arbor. 34: 301-373.

Stein, W. E., Jr., D. C. Wight, And C. B. Beck. 1982. Techniques for preparation of pyrite and limonite per- mineralizations. Rev. Palaeobot. Palynol. 36: 185194.

Stewart, W. N. 1983. Paleobotany and the evolution of plants. Cambridge University Press, Cambridge.

TAYLOR, T. N. 1981. Paleobotany: an introduction to fossil plant biology. McGraw-Hill, New York.

TrevisAn, L. 1980. Ultrastructural notes and considerations of Ephedrites, Eucommiidites and Monosulcites pollen grains from Lower Cretaceous sediments of southern Tuscany (Italy). Pollen Spores 22: 85-132.

WhITE, DAvid. 1912. The characters of the fossil plant Gigantopteris Schenk and its occurrence in North America. Proc. U.S. Natl. Mus. 41: 493-516. 